\title{
Hydrogen sulfide and the vasculature: a novel vasculoprotective entity and regulator of nitric oxide bioavailability?
}

\author{
Matthew Whiteman ${ }^{a, *}$, Philip K. Moore ${ }^{b}$ \\ ${ }^{a}$ Institute of Biomedical and Clinical Science, Peninsula Medical School, St. Luke's Campus, Exeter, UK \\ ${ }^{b}$ Pharmaceutical Science Division, King's College London, London, UK
}

Received: September 12, 2008; Accepted: December 17, 2008

- Introduction

- Reactive nitrogen species (RNS) in the heart and vasculature

- $\left(\mathrm{H}_{2} \mathrm{~S}\right)$ biosynthesis

- $\mathrm{H}_{2} \mathrm{~S}$ measurement, catabolism and removal
- $\mathrm{H}_{2} \mathrm{~S}$ in the heart and vasculature

- Evidence for 'cross-talk' between nitric oxide and $\mathrm{H}_{2} \mathrm{~S}$

- Evidence for the formation of a novel intermediate between nitric oxide and $\mathrm{H}_{2} \mathrm{~S}$ at physiological $\mathrm{pH}$

- Concluding remarks

\begin{abstract}
Hydrogen sulfide $\left(\mathrm{H}_{2} \mathrm{~S}\right)$ is a well known and pungent toxic gas that has recently been shown to be synthesised in man from the amino acids cystathionine, homocysteine and cysteine by at least two distinct enzymes; cystathionine- $\gamma$-lyase and cystathionine- $\beta$-synthase. In the past few years, $\mathrm{H}_{2} \mathrm{~S}$ has emerged as a novel and increasingly important mediator in the cardiovascular system but delineating the precise physiology and pathophysiology of $\mathrm{H}_{2} \mathrm{~S}$ is proving to be complex and difficult to unravel with disparate findings reported with cell types, tissue types and animal species reported. Therefore, in this review we summarize the mechanisms by which $\mathrm{H}_{2} \mathrm{~S}$ has been proposed to regulate blood pressure and cardiac function, discuss the mechanistic discrepancies reported in the literature as well as the therapeutic potential of $\mathrm{H}_{2} \mathrm{~S}$. We also examine the methods of $\mathrm{H}_{2} \mathrm{~S}$ detection in biological fluids, processes for $\mathrm{H}_{2} \mathrm{~S}$ removal and discuss the reported blood levels of $\mathrm{H}_{2} \mathrm{~S}$ in man and animal models of cardiovascular pathology. We also highlight the complex interaction of $\mathrm{H}_{2} \mathrm{~S}$ with nitric oxide in regulating cardiovascular function in health and disease.
\end{abstract}

Keywords: nitrosothiol • cardioprotection • KATP • vasodilator • gaseous mediators • reactive nitrogen species $\bullet$ sulfur

\section{Introduction}

Hydrogen sulfide (dihydrogen sulfide, $\mathrm{H}_{2} \mathrm{~S}$ ) is a well known and pungent toxic gas and its toxicology as an environmental pollutant has been extensively studied [1]. Since it was first discovered to be synthesized in human tissues a decade ago, it has attracted substantial interest. Studies in animals have shown $\mathrm{H}_{2} \mathrm{~S}$ to be involved in several physiological and pathophysiological processes as diverse as learning and memory, chronic inflammation and the regulation of blood pressure. It will not have escaped the reader's attention that these processes are also tightly regulated by the much better understood gasesous mediator, nitric oxide. The similarity in physiological and pathophysiological effects between nitric oxide and $\mathrm{H}_{2} \mathrm{~S}$ has led to speculation about the existence of cellular

*Correspondence to: Dr. Matt WHITEMAN, Institute of Biomedical and Clinical Science, Peninsula Medical School, St. Luke's Campus, 'cross-talk' between the two gases and the enzymes responsible for their synthesis.

It should be noted here that although the words sulfur and sulphur are widespread in the scientific literature, predominantly from United States and UK/ UK-Commonwealth based researchers, respectively, an etymological basis for the spelling of sulphur is lacking. Sulfur is Latin and not Greek (the Greek for sulfur being thion) although both terms continue to be used interchangeably. However, it should be noted that the International Union of Pure and Applied Chemistry (IUPAC) applied the spelling of 'sulfur' in 1990 [2]. This was subsequently adopted by the nomenclature committee of the Royal Society of Chemistry (UK) in 1992 [3]. As such and to avoid confusion, we refer to $\mathrm{H}_{2} \mathrm{~S}$ as hydrogen sulfide.

Magdalen Road, Exeter, EX1 2LU, UK.

Tel.: +44 (0) 1392 262942; Fax: +44 (0) 1392262926

E-mail: matt.whiteman@pms.ac.uk; m.whiteman@exeter.ac.uk 


\section{Reactive nitrogen species (RNS) in the heart and vasculature}

Nitric oxide and peroxynitrite $\left(\mathrm{ONOO}^{-}\right)$are RNS formed in vivo (extensively reviewed in [4]). Nitric oxide is a free radical gas synthesized enzymatically from the amino acid L-arginine in a number of tissues using the three isoforms of nitric oxide synthase (NOS). Classically, NOS1 and NOS-3 are constitutively expressed and require $\mathrm{Ca}^{2+}$ calmodulin to produce low $\mathrm{nM}$ quantities of nitric oxide over short periods of time. NOS2 is an inducible $\mathrm{Ca}^{2+}$-independent isoform and synthesizes high $\mu \mathrm{M}$ concentrations of nitric oxide over a period of hours. Nitric oxide is important in the endotheliumdependent regulation of blood flow and pressure, inhibiting the activation of blood platelets, neurotransmission and memory (long-term potentiation; LTP). Nitric oxide is also involved with host-defence and the inflammatory cascade (exhaustively reviewed in [4]). Since the half-life of nitric oxide at physiological $\mathrm{pH}$ is $<5 \mathrm{~s}$, its formation in vivo can be quantitated by the measurement of its stable oxidation products, nitrite $\left(\mathrm{NO}_{2}{ }^{-}\right)$and nitrate $\left(\mathrm{NO}_{3}{ }^{-}\right)$and from the $S$-nitrosation of free or protein thiols ( $S$-nitrosothiols) [4].

The roles of nitric oxide and $\mathrm{ONOO}^{-}$in the cardiovascular system have been exhaustively studied and reviewed in great detail elsewhere $[4,7]$. Briefly, nitric oxide, through the activation of the $\mathrm{Ca}^{2+} /$ calmodulin-dependent enzymes NOS1 and NOS3 maintains cardiac function and vascular patency through direct endothelialdependent interaction with soluble guanylate cylcase resulting in cGMP accumulation, intracellular protein phosphorylation and vasorelaxation. In conditions such as sepsis, shock or inflammation, a third isoform, NOS2 is induced resulting in high concentrations of nitric oxide being synthesized and potentially lethal hypotension. Administration of NOS2 inhibitors effectively attenuate this hypotension in animal models. In otherwise healthy individuals or animals, the administration of NOS3 or more recently NOS1 [8] inhibitors alone can increase blood pressure clearly demonstrating a role for nitric oxide in regulating blood pressure homeostasis under physiological conditions. Similarly, nitric oxide donating drugs exert potent hypotensive actions $[9,10]$.

In the vasculature, $\mathrm{ONOO}^{-}$formation through substantially elevated nitric oxide synthesis can lead to endothelial lipid peroxidation, oxidation, nitration and inactivation of $\mathrm{Ca}^{2+}$-dependent vascular smooth muscle cell ATPases. ONOO- ${ }^{-}$-mediated oxidation of low-density lipoprotein also leads to the activation of macrophage scavenge receptor to precipitate atherosclerosis as well as directly induce smooth muscle and endothelial cell death. Since this will ultimately lead to impaired vascular response, the physiological removal of $\mathrm{ONOO}^{-}$by antioxidants, decomposition catalysts [4] or thiols (perhaps including hydrogen sulfide [11]) is considered beneficial in maintaining a healthy vasculature.

\section{$\mathrm{H}_{2} \mathrm{~S}$ biosynthesis}

$\mathrm{H}_{2} \mathrm{~S}$ is rapidly emerging as an important gaseous mediator in the vasculature. In sharp contrast to nitric oxide, and as one would expect from an emerging field of research, its vascular effects, its mechanism of action as well as the processes controlling the regulation of its synthesis are poorly understood. As with nitric oxide, $\mathrm{H}_{2} \mathrm{~S}$ is a highly lipophilic molecule and freely penetrates cells of all types. Whether or not $\mathrm{H}_{2} \mathrm{~S}$ and nitric oxide exert their effects in vivo independently or in tandem is currently not known but a growing body of literature is highly suggestive of $\mathrm{H}_{2} \mathrm{~S}$ involvement in the regulation of nitric oxide mediated signalling events and/or vice versa.

The bulk of endogenous $\mathrm{H}_{2} \mathrm{~S}$ synthesis in mammalian tissues appears to be from the pyridoxal-5'-phosphate-dependent enzymes cystathionine- $\gamma$-lyase (CSE; E.C. 4.4.1.1) and cystathionine- $\beta$-synthase (CBS; E.C. 4.2.1.22) and by analogy with NOS use amino acids as substrates; in this case cystathionine, cysteine and homocysteine (summarized in Fig. 1). $\mathrm{H}_{2} \mathrm{~S}$ may also be formed in vivo from the enzymatic desulfuration of $\beta$-mercaptopyruvate derived from cysteine transamination [12] although it is currently uncertain how this pathway contributes to the levels of $\mathrm{H}_{2} \mathrm{~S}$ reported in mammalian tissues (see below). In should be noted at this point that in aqueous solution $\mathrm{H}_{2} \mathrm{~S}$ is weakly acidic (pKa at $37^{\circ} \mathrm{C}, 6.76$ ) and dissociates to form two dissociation states; the hydrosulfide anion $\left(\mathrm{HS}^{-}\right)$, pKa 7.04 and sulfide anion $\left(\mathrm{S}^{2-}\right)$, pKa 11.96 according to the following sequential reactions

$$
\mathrm{H}_{2} \mathrm{~S} \rightleftharpoons \mathrm{HS}^{-}+\mathrm{H}^{+} \rightleftharpoons \mathrm{S}^{2-}+2 \mathrm{H}^{+}
$$

As such, at physiological pH of 7.4 approximately $18.5 \%$ of the total sulfide exists as the undissociated acid and $81.5 \%$ as the $\mathrm{HS}^{-}$anion [13]. Therefore, since it is currently not known whether the biological effects of $\mathrm{H}_{2} \mathrm{~S}$ are mediated directly by $\mathrm{H}_{2} \mathrm{~S}$ itself or derived species that will also exist at pH 7.4 (such as $\mathrm{S}^{2-}$ or $\mathrm{HS}^{-}$), we prudently use the term $\mathrm{H}_{2} \mathrm{~S}$ in this review to reflect the sum of these species present at physiological pH.

The human gene for CSE is located on chromosome 1 (1p31.1) and two possible splice variants of CSE mRNA have been characterized although their precise function in $\mathrm{H}_{2} \mathrm{~S}$ synthesis are unknown. CSE expression is induced in liver, kidney and lung by proinflammatory mediators such as lipopolysaccharide [14] and also in animal models of type I diabetes mellitus [15] and pancreatitis [16] although the precise molecular pathways for the induced expression of CSE and activity remain elusive. Similarly, the human CBS gene is located on chromosome 21 (21q22.3) [17] and encodes several mRNA [18] but the function of these mRNA isoforms in terms of $\mathrm{H}_{2} \mathrm{~S}$ synthesis are not known. However, it has been suggested that the heme component of CBS functions as a cellular redox sensor [19] perhaps increasing $\mathrm{H}_{2} \mathrm{~S}$ generation in response to intracellular oxidant load. Interestingly, CBS is allosterically regulated by $S$-adenosylmethionine [20] and stimulation of CBS activity increases glutathione (GSH) synthesis by promoting cellular cysteine uptake and accompanying increased $\gamma$-glutamylcysteine synthetase activity [21, 22] suggesting a role for CBS (and perhaps $\mathrm{H}_{2} \mathrm{~S}$ ) in addressing intracellular redox imbalances due to increased oxidant load. In agreement, $\mathrm{H}_{2} \mathrm{~S}$ or species derived from it at physiological $\mathrm{pH}$, react with several cytotoxic oxidant species such as hypochlorite [23], peroxynitrite [10], hydrogen peroxide, $\mathrm{O}_{2}{ }^{-}$ $[24,25]$ and nitric oxide [26] and prevent cell death induced by these oxidants suggesting a cytoprotective function for $\mathrm{H}_{2} \mathrm{~S}$. 


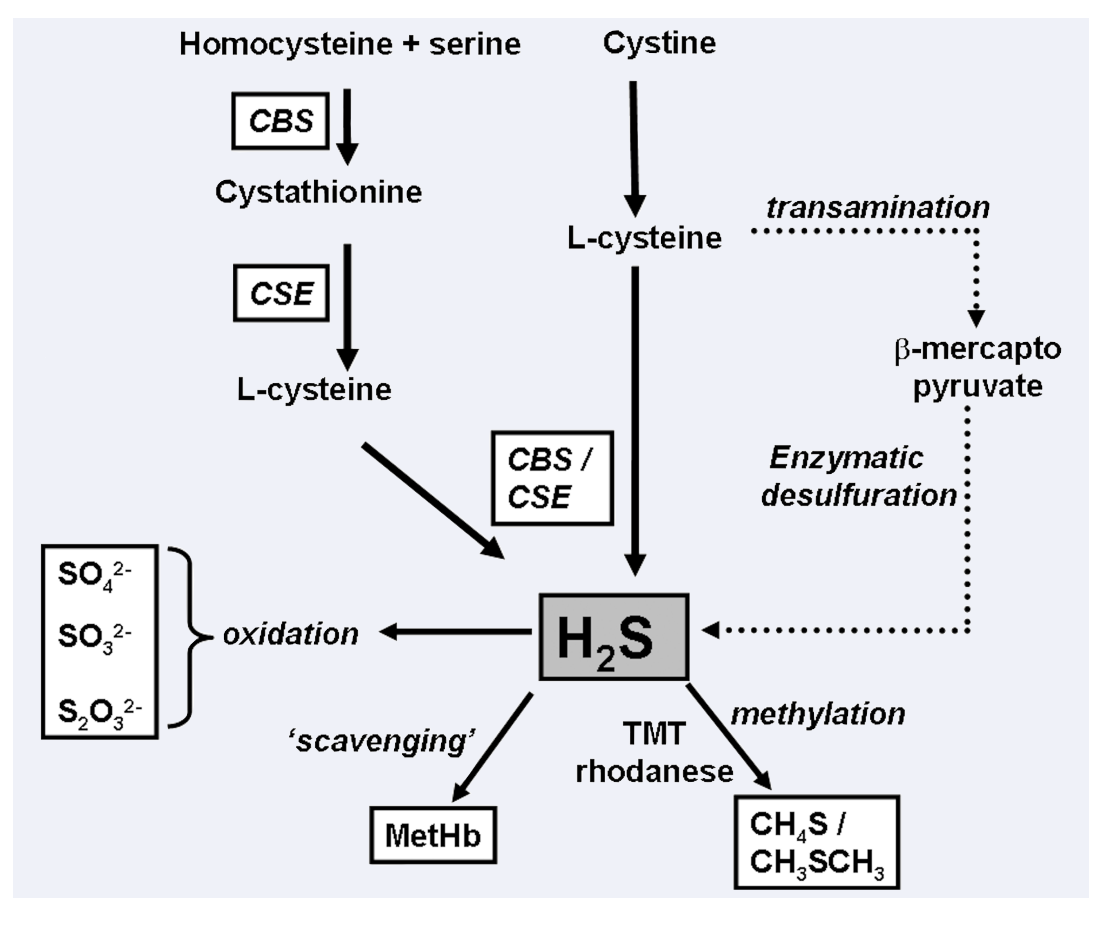

Fig. 1 Major Pathways of $\mathrm{H}_{2} \mathrm{~S}$ synthesis in vivo. $\mathrm{H}_{2} \mathrm{~S}$ is synthesized from the amino acids $\mathrm{L}$-cysteine and L-cystathionine by one of two enzymes (depending on cell type), cystathionine- $\beta$-synthase (CBS) and cystathionine- $\gamma$ lyase (CSE). Aminooxyacetate and propargylglycine (PAG) are commonly used inhibitors of CBS and CSE activity, respectively. The most prominent source of $\mathrm{H}_{2} \mathrm{~S}$ in the vasculature is CSE. Removal of $\mathrm{H}_{2} \mathrm{~S}$ is thought to occur via oxidation to sulfate $\left(\mathrm{SO}_{4}{ }^{2-}\right)$, sulfite $\left(\mathrm{SO}_{3}{ }^{2-}\right)$ and thiosulfate $\left(\mathrm{S}_{2} \mathrm{O}_{3}{ }^{2-}\right)$, scavenging by methemoglobin (MetHb) or methylation by enzymes such as thiolmethyltransferase (TMT) and rhodanese to form methanethio $\left(\mathrm{CH}_{4} \mathrm{~S}\right)$ and dimethylsulfide $\left(\mathrm{CH}_{3} \mathrm{SCH}_{3}\right)$.

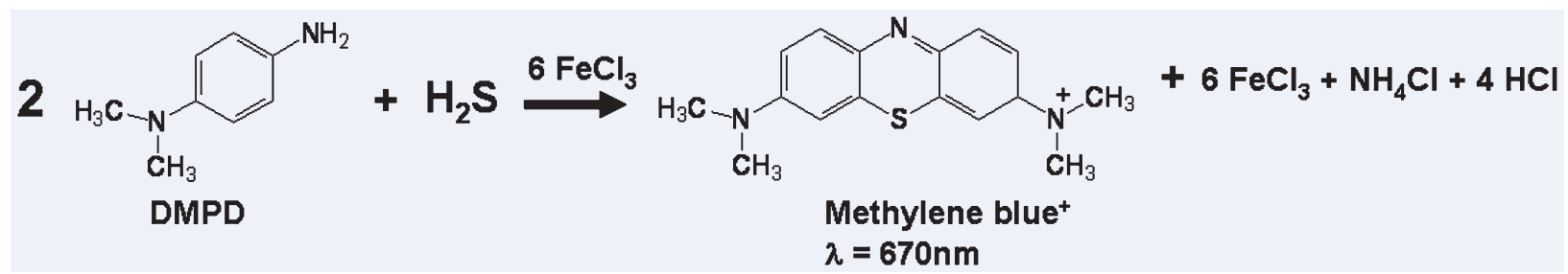

Fig. 2 Methylene blue assay for $\mathrm{H}_{2} \mathrm{~S}$ in biological fluids. This is the most simple and widely used assay for determining $\mathrm{H}_{2} \mathrm{~S}$ levels in body fluids. Using this and other methods (see Table 1), healthy human blood has been found to contain $\sim 30-60 \mu \mathrm{M}$ of $\mathrm{H}_{2} \mathrm{~S}$. $\mathrm{H}_{2} \mathrm{~S}$ levels are reduced in hypertension and increased during endotoxic or haemorrhagic shock. Modified from [31].

As with the various isoforms of NOS, CSE and CBS are widely expressed in human tissues and cells although a degree of tissue specificity is apparent. CBS is highly expressed in neuronal tissue, in particular in cerebellar Purkinje and hippocampal neurons. In contrast, CSE activity is most notable in blood vessels and peripheral tissues [27]. The liver of several species, including human beings, contain high levels of CSE and CBS expression and activity. Although there has been considerable interest in CSE and CBS over several decades due to their role in the trans-sulfuration pathway and homocysteine metabolism, very little is known about the precise molecular pathways for $\mathrm{H}_{2} \mathrm{~S}$ synthesis from these enzymes. In neuronal tissue, CBS activity appears $\mathrm{Ca}^{2+} /$ calmodulin-dependent suggesting that short-term control $\mathrm{H}_{2} \mathrm{~S}$ synthesis may be achieved by $\mathrm{Ca}^{2+}$ influx following neuronal depolarization [28] in a similar process to the synthesis of nitric oxide from the calcium/calmodulin-dependent NOS. The high endogenous concentrations of $\mathrm{H}_{2} \mathrm{~S}$ measured in human, rat and bovine brain (between 50 and $160 \mu \mathrm{m}$ ) has led to the suggestion that like nitric oxide, $\mathrm{H}_{2} \mathrm{~S}$ may function as an endogenous neuromodulator $[29,30]$.

\section{$\mathrm{H}_{2} \mathrm{~S}$ measurement, catabolism and removal}

At present there are no known specific and reliable stable end products of $\mathrm{H}_{2} \mathrm{~S}$ biosynthesis in the same way that $\mathrm{NO}_{2}{ }^{-} / \mathrm{NO}_{3}{ }^{-}$ function as a robust index of NOS activity in vivo. The majority of studies which have evaluated serum or plasma levels of $\mathrm{H}_{2} \mathrm{~S}$ have used a spectrophotometric approach based around methylene blue. This assay involves the 'fixing' or 'trapping' of aqueous sulfide in biological samples with zinc acetate to prevent unnecessary loss of $\mathrm{H}_{2} \mathrm{~S}$ through volatilization or through aerial oxidation resulting in the formation of stable zinc sulfide [31]. Upon subsequent acidification, $\mathrm{H}_{2} \mathrm{~S}$ is released and in the presence of $\mathrm{N}, \mathrm{N}$ dimethyl-p-phenylenediamine (DMPD) and of small quantities of ferric ions, the heterocyclic thiazine dye methylene blue produced can be readily measured using standard laboratory spectrophotometers at $670 \mathrm{~nm}$ (Fig. 2) [31] or analysed by high-performance liquid chromatography (see Table 1 for comparison of methods and levels of $\mathrm{H}_{2} \mathrm{~S}$ reported in mammalian serum and plasma). It is possible that this spectrophotometric assay measures the sum of 
Table 1 Comparison of plasma and serum levels of $\mathrm{H}_{2} \mathrm{~S}$ determined by several commonly used techniques: relevance to the cardiovascular system

\begin{tabular}{|c|c|c|c|c|c|c|}
\hline Species & Model & $\begin{array}{l}\text { Method of } \mathrm{H}_{2} \mathrm{~S} \\
\text { detection }\end{array}$ & Fluid & $\mathrm{H}_{2} \mathrm{~S}$ level reported & Comment & References \\
\hline $\begin{array}{l}\text { Male Sprague- } \\
\text { Dawley rats }\end{array}$ & $\begin{array}{l}\text { Myocardial injury } \\
\text { induced by homo- } \\
\text { cysteine treatment }\end{array}$ & $\begin{array}{l}\text { Commercial } \\
\text { sulfide-sensitive } \\
\text { electrode }\end{array}$ & Plasma & $\begin{array}{l}\text { Control rats, } ~ 30 \\
\mu \mathrm{M}^{*} \text { Homocysteine } \\
\text { treatment, } 50 \\
\mu \mathrm{M}^{*}\end{array}$ & $\begin{array}{l}\text { Homocysteine is a substrate for CSE. } \\
\mathrm{H}_{2} \mathrm{~S} \text { prevented myocardial injury. CSE } \\
\text { expression and activity were lowered } \\
\text { by high concentrations of } \mathrm{H}_{2} \mathrm{O}_{2} \\
(0.1-10 \mathrm{mM})\end{array}$ & [34] \\
\hline $\begin{array}{l}\text { Rats - species not } \\
\text { specified }\end{array}$ & $\begin{array}{l}\text { Isoproterenol- } \\
\text { induced myocardial } \\
\text { injury }\end{array}$ & $\begin{array}{l}\text { Zinc acetate / N,N- } \\
\text { dimethyl- } \\
\text { p-phenylenedi- } \\
\text { amine (DMPD) }\end{array}$ & Plasma & $\begin{array}{l}\text { Control rats, } \\
\sim 65 \mu \mathrm{M}^{*} \\
\text { Isoprotenerol } \\
\text { treated rats, } \\
\sim 18 \mu \mathrm{M}^{*}\end{array}$ & $\begin{array}{l}\text { CSE involved in mediating cardiac } \\
\text { contraction. Treatment of rats with iso- } \\
\text { proterenol and NaHS significantly low- } \\
\text { ered CPK and LDH release from } \\
\text { myocardial tissue, lowered the levels } \\
\text { of lipid peroxidation products and pre- } \\
\text { served left ventricular function. NaHS } \\
\text { increased survival, induced capillary } \\
\text { dilatation and reduced leucocyte infil- } \\
\text { tration into myocardial tissue. Part of } \\
\text { the mechanism for these observations } \\
\text { may include } \mathrm{H}_{2} \mathrm{~S}-\text { mediated 'scaveng- } \\
\text { ing' of } \mathrm{H}_{2} \mathrm{O}_{2} \text { and } \mathrm{O}_{2}^{-} \text {. }\end{array}$ & [25] \\
\hline $\begin{array}{l}\text { Male Sprague- } \\
\text { Dawley rats }\end{array}$ & $\begin{array}{l}\text { Endotoxemia } \\
\text { induced by bacter- } \\
\text { ial lipopolysaccha- } \\
\text { ride from E. Coli }\end{array}$ & $\begin{array}{l}\text { Zinc acetate / } \\
\text { DMPD }\end{array}$ & Plasma & $\begin{array}{l}\text { Control rats, } 26 \\
\mu \mathrm{M}^{*} \text { LPS treated } \\
\text { rats, } \sim 45 \mu \mathrm{M}^{*}\end{array}$ & $\begin{array}{l}\text { LPS increase plasma } \mathrm{PGE}_{2} \text { levels; an } \\
\text { effect decreased by the } \mathrm{H}_{2} \mathrm{~S} \text {-releasing } \\
\text { drug } S \text {-diclofenac LPS increased } \\
\text { plasma } \mathrm{NO}_{2}{ }^{-} \text {levels; decreased by } \\
\text { S-diclofenac suggesting } \mathrm{H}_{2} \mathrm{~S} \text {-nitric } \\
\text { oxide cross-talk }\end{array}$ & [113] \\
\hline $\begin{array}{l}\text { Male Sprague- } \\
\text { Dawley rats, WKY } \\
\text { rats, } \\
\text { Spontaneously } \\
\text { hypertensive rats } \\
\text { (SHR) }\end{array}$ & $\begin{array}{l}\text { Development of a } \\
\text { novel slow releas- } \\
\text { ing } \mathrm{H}_{2} \mathrm{~S} \text { donor } \\
\text { (GYY4137); } \\
\text { Hypertension: } \\
\text { induced by } \\
\text { L-NAME induced } \\
\text { hypertension, nor- } \\
\text { motensive rats and } \\
\text { SHR }\end{array}$ & $\begin{array}{l}\text { Zinc acetate / } \\
\text { DMPD }\end{array}$ & Plasma & $\begin{array}{l}\text { Baseline levels of } \\
\sim 35 \mu \mathrm{M}^{*} \text { rose to } \\
\sim 80 \mu \mathrm{M}^{\star} 90 \text { min } \\
\text { after i.v. or i.p. } \\
\text { administration of } \\
\mathrm{H}_{2} \mathrm{~S} \text { donor. }\end{array}$ & $\begin{array}{l}\text { First demonstration of the biphasic } \\
\text { effects of } \mathrm{H}_{2} \mathrm{~S} \text { on cardiac function. } \\
\text { Rapid release of } \mathrm{H}_{2} \mathrm{~S} \text { by NaHS reduced } \\
\text { cardiac contractility (left ventricular } \\
\text { diastolic pressure) by } 42 \% \text { and heart } \\
\text { rate by } 53 \% \text {. In contrast, the slow and } \\
\text { sustained release of } \mathrm{H}_{2} \mathrm{~S} \text { via GYY } 4137 \\
\text { had no effect on cardiac contractility } \\
\text { or heart rate. NaHS increased mean } \\
\text { arterial blood pressure in L-NAME } \\
\text { treated rats whereas GYY4137 pre- } \\
\text { vented L-NAME-induced hypertension. } \\
\text { Furthermore GYY4137 markedly } \\
\text { reduced systolic pressure in SHR but } \\
\text { not WKY rats. }\end{array}$ & [79] \\
\hline $\begin{array}{l}\text { Male Sprague- } \\
\text { Dawley rats }\end{array}$ & $\begin{array}{l}\text { Type I diabetes } \\
\text { induced by strepto- } \\
\text { zotocin (STZ) }\end{array}$ & $\begin{array}{l}\text { Zinc acetate / } \\
\text { DMPD }\end{array}$ & Plasma & $\begin{array}{l}\text { Control rats, } \sim 40 \\
\mu \mathrm{M} \text { STZ treated } \\
\text { rats, } \sim 38 \mu \mathrm{M}\end{array}$ & $\begin{array}{l}\text { Insulin treatment significantly elevated } \\
\text { plasma } \mathrm{H}_{2} \mathrm{~S} \text { levels. STZ elevated liver, } \\
\text { kidney and pancreas CSE and CBS } \\
\text { expression and activity. STZ is a nitric } \\
\text { oxide donating molecule and the } \\
\text { decreased plasma levels of } \mathrm{H}_{2} \mathrm{~S} \text { after } \\
\text { STZ treatment could reflect consump- } \\
\text { tion of } \mathrm{H}_{2} \mathrm{~S} \text { by nitric oxide and / or } \\
\text { derived intermediates }\end{array}$ & [15] \\
\hline
\end{tabular}


Table 1 Continued

\begin{tabular}{|c|c|c|c|c|c|c|}
\hline Species & Model & $\begin{array}{l}\text { Method of } \mathrm{H}_{2} \mathrm{~S} \\
\text { detection }\end{array}$ & Fluid & $\mathrm{H}_{2} \mathrm{~S}$ level reported & Comment & References \\
\hline $\begin{array}{l}\text { Male Sprague- } \\
\text { Dawley rats }\end{array}$ & $\begin{array}{l}\text { High blood-flow } \\
\text { induced pulmonary } \\
\text { hypertension } \\
\text { induced by abdom- } \\
\text { inal aorta-inferior } \\
\text { cava vein shunt }\end{array}$ & $\begin{array}{l}\text { Zinc acetate / } \\
\text { DMPD }\end{array}$ & Plasma & $\begin{array}{l}\text { Control rats, } 50.9 \\
\pm 3.9 \mu \mathrm{M} \\
\text { Pulmonary hyper- } \\
\text { tensive rats, } 36.4 \\
\pm 2.6 \mu \mathrm{M}\end{array}$ & $\begin{array}{l}\text { Shunt decreased CSE mRNA expression in } \\
\text { lung CSE mRNA localized in smooth mus- } \\
\text { cle cells on small pulmonary muscular } \\
\text { arteries with minimal expression in } \\
\text { endothelial cells }\end{array}$ & [110] \\
\hline $\begin{array}{l}\text { Male Sprague- } \\
\text { Dawley rats }\end{array}$ & $\begin{array}{l}\text { High blood flow } \\
\text { induced pulmonary } \\
\text { hypertension } \\
\text { induced by abdom- } \\
\text { inal aorta-inferior } \\
\text { cava vein shunt }\end{array}$ & $\begin{array}{l}\text { Zinc acetate / } \\
\text { DMPD }\end{array}$ & Plasma & $\begin{array}{l}\text { Control rats, } 50.83 \\
\pm 4.01 \mu \mathrm{M} \text { Shut, } \\
36.42 \pm 3.12 \mu \mathrm{M}\end{array}$ & $\begin{array}{l}\text { Shunting decreased CSE mRNA expression } \\
\text { in medial and small pulmonary arteries and } \\
\text { rate of } \mathrm{H}_{2} \mathrm{~S} \text { synthesis in lung tissue }\end{array}$ & [111] \\
\hline $\begin{array}{l}\text { Male WKY and } \\
\text { spontaneous } \\
\text { hypertensive (SHR) } \\
\text { rats }\end{array}$ & Hypertension & $\begin{array}{l}\text { Zinc acetate / } \\
\text { DMPD }\end{array}$ & Plasma & $\begin{array}{l}\text { WKY rats } 48 \pm 13 \\
\mu \mathrm{M} \text { SHR rats } 20 \pm \\
9 \mu \mathrm{M}\end{array}$ & $\begin{array}{l}\text { PAG treatment decreased H2S levels in } \\
\text { WKY (to } 21 \pm 7 \mu \mathrm{M} \text { ) and SHR (to } 12 \pm \\
10 \mu \mathrm{M} \text { ) and also increased the expression } \\
\text { of CSE in aorta in WKY and SHR suggest- } \\
\text { ing } \mathrm{H}_{2} \mathrm{~S} \text { involvement in regulation of blood } \\
\text { pressure }\end{array}$ & [61] \\
\hline $\begin{array}{l}\text { Male Sprague- } \\
\text { Dawley rats }\end{array}$ & $\begin{array}{l}\text { Haemorrhagic } \\
\text { shock (blood with- } \\
\text { drawl, } 9-10 \mathrm{ml} \text { over } \\
\text { an hour in } 2 \text { min } \\
\text { periods) }\end{array}$ & $\begin{array}{l}\text { Zinc acetate / } \\
\text { DMPD }\end{array}$ & Plasma & $\begin{array}{l}\text { Prior to blood } \\
\text { withdrawl, } 28.9 \pm \\
1.4 \mu \mathrm{M} 60 \mathrm{~min} \\
\text { after blood with- } \\
\text { drawl, } 37.5 \pm 1.3 \\
\mu \mathrm{M}\end{array}$ & $\begin{array}{l}\text { PAG or } \beta \text {-cyanoalanine injected either pro- } \\
\text { phylactically or therapeutically, inhibited } \\
\text { the increase in plasma } \mathrm{H}_{2} \mathrm{~S} \text { and drop in } \\
\text { mean arterial blood pressure. This } \\
\text { response was not inhibited by gliben- } \\
\text { clamide (KATP channel antagonist). Blood } \\
\text { withdrawl increased liver CSE mRNA } \\
\text { expression }\end{array}$ & [62] \\
\hline Wistar rats & $\begin{array}{l}\text { Hypoxic pulmonary } \\
\text { hypertension } \\
\text { (HPH) }\end{array}$ & $\begin{array}{l}\text { Zinc acetate / } \\
\text { DMPD }\end{array}$ & Plasma & $\begin{array}{l}\text { Control rats, } 301.6 \\
\pm 32.41 \mu \mathrm{M} \mathrm{HPH} \\
92.2 \pm 22.1 \mu \mathrm{M}\end{array}$ & $\begin{array}{l}\text { NaHS increased lung CSE expression; lev- } \\
\text { els of control rats approximately } 10 \text { fold } \\
\text { higher than the reported findings of others } \\
\text { with the same species of rat (see below). } \\
\text { Nevertheless, } \mathrm{HPH} \text { induced a significant } \\
\text { decrease in plasma } \mathrm{H}_{2} \mathrm{~S} \text {. }\end{array}$ & [43] \\
\hline Male Wistar rats & $\begin{array}{l}\text { Myocardial infarc- } \\
\text { tion; ligation of left } \\
\text { anterior descend- } \\
\text { ing artery from its } \\
\text { origin between the } \\
\text { pulmonary artery } \\
\text { conus and the left } \\
\text { atrium }\end{array}$ & $\begin{array}{l}\text { Zinc acetate / } \\
\text { DMPD }\end{array}$ & Plasma & $\begin{array}{l}\text { Control rats, } 38.2 \\
\pm 2.07 \mu \mathrm{M} 48 \mathrm{hrs} \\
\text { after } \mathrm{Ml} \text { induction, } \\
59.2 \pm 7.16 \mu \mathrm{M}\end{array}$ & $\begin{array}{l}\text { PAG treatment reduced plasma } \mathrm{H}_{2} \mathrm{~S} \text { levels } \\
\text { to } 39.2 \pm 5.02 \mu \mathrm{M} \text { whereas treatment with } \\
\text { the } \mathrm{H}_{2} \mathrm{~S} \text { donor, } \mathrm{NaHS} \text {, significantly } \\
\text { increased plasma } \mathrm{H}_{2} \mathrm{~S} \text { levels to } 92.2 \pm \\
12.40 \mu \mathrm{M} . \mathrm{MI} \text { and PAG treatment } \\
\text { decreased CSE mRNA expression. PAG } \\
\text { treatment reduced myocardial oedema and } \\
\text { inflammatory cell infiltrate. CSE immunore- } \\
\text { activity detected in infarct area as well as } \\
\text { in the endothelium of small vessels of area } \\
\text { at-risk. In contrast, CSE was not detected } \\
\text { in cardiomyocytes under these experimen- } \\
\text { tal conditions. }\end{array}$ & [70] \\
\hline
\end{tabular}


Table 1 Continued

\begin{tabular}{|c|c|c|c|c|c|c|}
\hline Species & Model & $\begin{array}{l}\text { Method of } \mathrm{H}_{2} \mathrm{~S} \\
\text { detection }\end{array}$ & Fluid & $\mathrm{H}_{2} \mathrm{~S}$ level reported & Comment & References \\
\hline Male Wistar rats & $\begin{array}{l}\text { Hypoxic pulmonary } \\
\text { hypertension }\end{array}$ & $\begin{array}{l}\text { Zinc acetate / } \\
\text { DMPD }\end{array}$ & Plasma & $\begin{array}{l}\text { Control group, } \\
299.6 \pm 12.4 \mu \mathrm{M} \\
\text { Hypoxia, } 187.2 \pm \\
13.1 \mu \mathrm{M}\end{array}$ & $\begin{array}{l}\text { NaHS increased lung CSE expression; } \\
\text { levels of control rats approximately } 10 \\
\text { fold higher than the reported findings of } \\
\text { others with the same species of rat . } \\
\text { Administration of NaHS to hypoxia } \\
\text { treated rats increased plasma } \mathrm{H}_{2} \mathrm{~S} \text { levels } \\
\text { to } 309.2 \pm 13.6 \mu \mathrm{M} \text { Potential antioxi- } \\
\text { dant action of } \mathrm{H}_{2} \mathrm{~S} \text { : Hypoxia decreased } \\
\text { plasma antioxidant enzyme superoxide } \\
\text { dismutase (SOD), increased levels of } \\
\text { oxidized glutathione (GSSG) and lipid } \\
\text { peroxidation markers (malondialde- } \\
\text { hyde); these effects were reversed by } \\
\text { NaHS administration. }\end{array}$ & [114] \\
\hline $\begin{array}{l}\text { Male Sprague- } \\
\text { Dawley rats }\end{array}$ & $\begin{array}{l}\text { Cardiac ischemia } \\
\text { reperfusion; occlu- } \\
\text { sion of left anterior } \\
\text { descending coro- } \\
\text { nary artery }\end{array}$ & $\begin{array}{l}\text { Zinc acetate / } \\
\text { DMPD }\end{array}$ & Plasma & $\begin{array}{l}\text { Control group, } \\
58.28 \pm 7.86 \mu \mathrm{M} \\
\text { Ischemia-reperfu- } \\
\text { sion group } 30.32 \\
\pm 5.26 \mu \mathrm{M}\end{array}$ & $\begin{array}{l}\text { NaHS decreased infarct size and } \\
\text { improved haemodynamics (increased } \\
\text { left ventricular diastolic pressure) } \\
\text { Suggested mechanism for cardioprotec- } \\
\text { tion via down-regulation of c-fos } \\
\text { expression in myocardium. }\end{array}$ & [115] \\
\hline $\begin{array}{l}\text { Male Sprague- } \\
\text { Dawley rats }\end{array}$ & & $\begin{array}{l}\text { Commercial } \\
\text { sulfide-sensitive } \\
\text { electrode }\end{array}$ & Plasma & $\begin{array}{l}\text { Healthy rats, } 45.6 \\
\pm 10.59 \mu \mathrm{M}\end{array}$ & & [109] \\
\hline $\begin{array}{l}\text { Lobund-Wistar } \\
\text { (LW) rats Harlan- } \\
\text { Sprague-Dawley } \\
\text { (HSD) rats C57 } \\
\text { Black/6 (C57) mice }\end{array}$ & $\begin{array}{l}\text { Method compari- } \\
\text { son study }\end{array}$ & $\begin{array}{l}\text { Polarographic } \\
\mathrm{H}_{2} \mathrm{~S} \text { sensor and } \\
\text { Ion-selective } \\
\text { electrode Zinc } \\
\text { acetate / DMPD }\end{array}$ & Plasma & $\begin{array}{l}\mathrm{H}_{2} \mathrm{~S} \text { was not } \\
\text { detected in } \mathrm{LW} \text { or } \\
\mathrm{HSD} \text { rats or } \mathrm{C} 57 \\
\text { mice. } \mathrm{H}_{2} \mathrm{~S} \text { was not } \\
\text { detected in } \mathrm{LW} \text { rats } \\
\text { but } 4.3 \pm 0.5 \mu \mathrm{M} \\
\text { detected in HSD rat } \\
\text { plasma. }\end{array}$ & $\begin{array}{l}\text { This study also shows the rapid } \\
\text { removal, metabolism or sequestration of } \\
\mathrm{H}_{2} \mathrm{~S} \text { added to vertebrate plasma; half } \\
\text { time of decay of } 10 \mu \mathrm{M} \mathrm{Na} 2 \mathrm{~S} \text { added to } \\
\text { plasma at } 37^{\circ} \mathrm{C}, 13.0 \pm 0.2 \mathrm{sec} \text {. }\end{array}$ & {$[38]$} \\
\hline $\begin{array}{l}\text { Male Swiss albino } \\
\text { mice }\end{array}$ & $\begin{array}{l}\text { Septic shock } \\
\text { (induced by LPS) }\end{array}$ & $\begin{array}{l}\text { Zinc acetate / } \\
\text { DMPD }\end{array}$ & Plasma & $\begin{array}{l}\text { Untreated animals, } \\
\sim 32 \mu \mathrm{M}^{*} \text { LPS } 4 \mathrm{hrs} \text {, } \\
\sim 40 \mu \mathrm{M} \text { LPS } 20 \mathrm{hrs} \text {, } \\
\sim 65 \mu \mathrm{M}\end{array}$ & $\begin{array}{l}\text { LPS induced liver and kidney CSE } \\
\text { expression and activity was inhibited } \\
\text { by PAG. } \mathrm{H}_{2} \mathrm{~S} \text { levels correlated with } \\
\text { myeloperoxidase expression and } \\
\text { activity. }\end{array}$ & [14] \\
\hline \multirow[t]{2}{*}{ Male Balb/C mice } & $\begin{array}{l}\text { Acute pancreatitis } \\
\text { induced by } \\
\text { caerulein }\end{array}$ & $\begin{array}{l}\text { Zinc acetate / } \\
\text { DMPD }\end{array}$ & Plasma & $\begin{array}{l}\text { Control mice, } 22.5 \\
\pm 1.9 \mu \mathrm{M} \\
\text { Caerulein treat- } \\
\text { ment, } 31.1 \pm 3.3 \\
\mu \mathrm{M}\end{array}$ & $\begin{array}{l}\text { Pancreatitis-induced CSE expression } \\
\text { elevated plasma } \mathrm{H}_{2} \mathrm{~S} \text { levels. PAG treat- } \\
\text { ment lowered plasma } \mathrm{H}_{2} \mathrm{~S} \text { levels, levels } \\
\text { pancreatic amylase and myeloperoxi- } \\
\text { dase activity, inhibited acinar cell death } \\
\text { and lung injury. }\end{array}$ & [116] \\
\hline & & & Plasma & $\begin{array}{l}\text { Control mice, 30 } \\
\mu \mathrm{M}^{\star} \text { Caerulein } \\
\text { treatment, } \sim 35 \\
\mu \mathrm{M}^{*}\end{array}$ & & [117] \\
\hline
\end{tabular}


Table 1 Continued

\begin{tabular}{|c|c|c|c|c|c|c|}
\hline Species & Model & $\begin{array}{l}\text { Method of } \mathrm{H}_{2} \mathrm{~S} \\
\text { detection }\end{array}$ & Fluid & $\mathrm{H}_{2} \mathrm{~S}$ level reported & Comment & References \\
\hline $\begin{array}{l}\text { Male Swiss } \\
\text { albino mice }\end{array}$ & $\begin{array}{l}\text { Cecal ligation and } \\
\text { puncture-induced } \\
\text { sepsis (CLP) }\end{array}$ & $\begin{array}{l}\text { Zinc acetate / } \\
\text { DMPD }\end{array}$ & Plasma & $\begin{array}{l}\text { Normal, 10 } \mu \mathrm{M}^{*} \text { Sham, } \\
\sim 13 \mu \mathrm{M}^{*} \mathrm{CLP}, 20 \mu \mathrm{M}^{*}\end{array}$ & $\begin{array}{l}\text { Sepsis-induced CSE expression and } \\
\text { elevated plasma } \mathrm{H}_{2} \mathrm{~S} \text { levels. Plasma } \\
\mathrm{H} 2 \mathrm{~S} \text { levels were significantly lowered } \\
\text { after prophylactic or therapeutic } \\
\text { treatment with PAG. }\end{array}$ & [118] \\
\hline $\begin{array}{l}\text { Female NOR/Ltj } \\
\text { and female } \\
\text { NOD/Ljt mice }\end{array}$ & $\begin{array}{l}\text { Non-obese diabetic } \\
\text { mouse model and } \\
\text { controls }\end{array}$ & $\begin{array}{l}\text { Zinc acetate / } \\
\text { DMPD }\end{array}$ & Plsama & $\begin{array}{l}\text { Control mice (NOR/Ljt), } \\
\sim 60 \mu \mathrm{M}^{\star} \text { NOD mice } \\
\text { stage I, } \sim 60 \mu \mathrm{M}^{*} \text { stage } \\
\text { II, } \sim 33 \mu \mathrm{M}^{*} \text { stage III, } \\
\sim 27 \mu \mathrm{M}^{*}\end{array}$ & $\begin{array}{l}\text { Plasma levels of } \mathrm{H}_{2} \mathrm{~S} \text { decreased } \\
\text { markedly as disease progressed. } \\
\mathrm{L} \text {-cysteine stimulated synthesis of } \\
\mathrm{H}_{2} \mathrm{~S} \text { and vasorelaxant effect in aortic } \\
\text { tissue were significantly decreased } \\
\text { with increasing disease progression. }\end{array}$ & [119] \\
\hline $\begin{array}{l}\text { Male C57BL/6J } \\
\text { mice }\end{array}$ & $\begin{array}{l}\text { Genetic knock-out } \\
\text { studies; Wild-type } \\
\left(\mathrm{CSE}^{+/+}\right), \mathrm{CSE}^{+/-} \\
\text {and } \mathrm{CSE}^{-/-}\end{array}$ & $\begin{array}{l}\text { Commerical } \\
\text { sulfide } \\
\text { ion-selective } \\
\text { electrode }\end{array}$ & Serum & $\begin{array}{l}\mathrm{CSE}^{+/+} \text {mice } \sim 40 \mu \mathrm{M}^{*} \\
\mathrm{CSE}^{+/-} \text {mice } \sim 31 \mu \mathrm{M}^{*} \\
\mathrm{CSE}^{-1-} \text { mice } \sim 18 \mu \mathrm{M}^{*}\end{array}$ & $\begin{array}{l}\mathrm{CSE}^{-/-} \text {mice had higher systolic blood } \\
\text { pressure than } \mathrm{CSE}^{+/-} \text {mice; } \mathrm{CSE}^{+/-} \\
\text {mice had higher systolic blood pressure } \\
\text { than } \mathrm{CSE}^{+/+} \text {mice. } \mathrm{CSE}^{-/-} \text {more sen- } \\
\text { sitive to } \mathrm{H}_{2} \mathrm{~S} \text {-induced vasodilatation } \\
\text { than } \mathrm{CSE}^{+/+} \text {. }\end{array}$ & [55] \\
\hline Human & $\begin{array}{l}\text { Chronic obstructive } \\
\text { pulmonary disease } \\
\text { (COPD); } 27 \\
\text { patients with acute } \\
\text { exacerbation of } \\
\text { COPD (AECOPD), } \\
37 \text { patients with } \\
\text { stable COPD }\end{array}$ & $\begin{array}{l}\text { Commercial } \\
\text { sulfide-sensitive } \\
\text { electrode }\end{array}$ & Serum: & $\begin{array}{l}\text { healthy volunteers; aged } \\
71-80 \mathrm{yrs}, 35.7 \pm 1.2 \mu \mathrm{M} \\
\text { aged } 61-70 \mathrm{yrs}, 34.0 \pm \\
0.9 \mu \mathrm{M} \text { aged } 50-60 \mathrm{yrs} \text {, } \\
36.1 \pm 1.1 \mu \mathrm{M} \text { No signif- } \\
\text { icant difference between } \\
\text { healthy and AECOPD } \\
\left(\sim 35 \mu \mathrm{M}^{\star}\right) \text { but elevated } \\
\text { to in stable COPD } \\
\text { patients (non-smokers, } \\
51.1 \pm 3.0 \mu \mathrm{M} \text {; smokers } \\
49.8 \pm 3.8 \mu \mathrm{M})\end{array}$ & $\begin{array}{l}\text { Smoking significantly lowered plasma } \\
\text { levels of } \mathrm{H}_{2} \mathrm{~S} \text { in healthy controls and } \\
\text { AECOPD patients. High levels of nitric } \\
\text { oxide (measured as total } \\
\text { nitrite/nitrate) correlated to higher } \mathrm{H}_{2} \mathrm{~S} \\
\text { levels. } \mathrm{H}_{2} \mathrm{~S} \text { levels also correlated with } \\
\text { stage of lung obstruction with COPD* } \\
\text { (Stage I, } \sim 72 \mu \mathrm{M} \text {; Stage II, } \sim 50 \mu \mathrm{M} \text {; } \\
\text { Stage III, } \sim 40 \mu \mathrm{M} \text {; Stage IV, } \sim 48 \mu \mathrm{M} \text { ) } \\
\mathrm{H}_{2} \mathrm{~S} \text { levels negatively correlated with } \\
\text { sputal neutrophil count and positively } \\
\text { with lung function (predicted } \mathrm{FEV}_{1} \text { ). }\end{array}$ & [33] \\
\hline Human & $\begin{array}{l}\text { Chronic obstructive } \\
\text { pulmonary disease } \\
\text { (COPD); } 18 \\
\text { patients before and } \\
\text { after theophylline } \\
\text { treatment }\end{array}$ & $\begin{array}{l}\text { Commercial } \\
\text { sulfide-sensitive } \\
\text { electrode }\end{array}$ & Serum & $\begin{array}{l}\text { COPD } 30-100 \mu \mathrm{M}^{\star} \\
\text { Serum levels unaffected } \\
\text { by theophylline treat- } \\
\text { ment. }\end{array}$ & $\begin{array}{l}\mathrm{H}_{2} \mathrm{~S} \text { levels positively correlated with } \\
\text { percentage of predicted } \mathrm{FEV}_{1} \text {, sputum } \\
\text { macrophage levels but negatively cor- } \\
\text { related with sputum neutrophil count. } \\
\text { Sputum levels of } \mathrm{H}_{2} \mathrm{~S} \text { were equivalent } \\
\text { to levels of } \mathrm{NO}_{2}^{-} \text {. }\end{array}$ & [120] \\
\hline Human & $\begin{array}{l}40 \text { patients with } \\
\text { coronary heart dis- } \\
\text { ease (CHD), } 17 \\
\text { angiographically } \\
\text { normal patients }\end{array}$ & $\begin{array}{l}\text { Commercial } \\
\text { sulfide-sensitive } \\
\text { electrode }\end{array}$ & Plasma: & $\begin{array}{l}\text { Normal controls, } 51.7 \pm \\
11.9 \mu \mathrm{M} \text { CHD, } 26.1 \pm \\
14.2 \mu \mathrm{M} \text { Single vessel } \\
\mathrm{CHD}, 33.0 \pm 15.0 \mu \mathrm{M} \\
\text { Double vessel CHD, } 16.9 \\
\pm 7.9 \mu \mathrm{M} \text { Multi-vessel } \\
\mathrm{CHD}, 18.4 \pm 7.8 \mu \mathrm{M} \\
\text { Unstable angina, } 23.6 \pm \\
14.4 \mu \mathrm{M} \text { Acute myocar- } \\
\text { dial infarction, } 19.9 \pm 7.5 \\
\mu \mathrm{M} \text { Stable angina, 38.4 } \pm \\
14.5 \mu \mathrm{M} \text { CHD with coro- } \\
\text { nary artery occlusion, }\end{array}$ & $\begin{array}{l}\text { Patients with CHD had significantly } \\
\text { lower } \mathrm{H}_{2} \mathrm{~S} \text { levels compared to angio- } \\
\text { graphically normal controls. The num- } \\
\text { ber of affected vessels correlated with } \\
\text { a decrease in } \mathrm{H}_{2} \mathrm{~S} \text { levels suggesting } \\
\text { decreased } \mathrm{H}_{2} \mathrm{~S} \text { levels correlate with } \\
\text { disease severity but could also reflect } \\
\text { either } \mathrm{H}_{2} \mathrm{~S} \text { consumption by vascular } \\
\text { oxidants. Plasma levels were also sig- } \\
\text { nificantly negatively correlated to } \\
\text { blood glucose levels and significantly } \\
\text { lower in smokers compared to non- } \\
\text { smokers. }\end{array}$ & {$[60]$} \\
\hline
\end{tabular}


Table 1 Continued

\begin{tabular}{|c|c|c|c|c|c|c|}
\hline Species & Model & $\begin{array}{l}\text { Method of } \mathrm{H}_{2} \mathrm{~S} \\
\text { detection }\end{array}$ & Fluid & $\mathrm{H}_{2} \mathrm{~S}$ level reported & Comment & References \\
\hline Human & $\begin{array}{l}\text { Essential hyperten- } \\
\text { sion in children }\end{array}$ & $\begin{array}{l}\text { Ionic conductance } \\
\text { meter/sulfide } \\
\text { specific detector }\end{array}$ & Plasma & $\begin{array}{l}\text { Control group } 65.7 \\
\pm 5.5 \mu \mathrm{M} \text { (mean } \\
\text { age } 10.5 \pm 0.73 \text { ) } \\
\text { Hypertensive chil- } \\
\text { dren (mean age } \\
10.48 \pm 3.2 \mathrm{yrs} \text { ) } \\
51.9 \pm 6.0 \mu \mathrm{M}\end{array}$ & $\begin{array}{l}\text { High plasma levels of } \mathrm{H}_{2} \mathrm{~S} \text { correlated } \\
\text { to low homocysteine concentrations. } \\
\text { Hypertensive children had a lower } \\
\mathrm{H}_{2} \mathrm{~S} \text { : homocysteine ratio compared to } \\
\text { the control group ( } 5.8 \pm 2.9 \text { cf. } 11.6 \\
\pm 3.3 \text { ). Higher systolic pressure was } \\
\text { associated with a lower plasma } \\
\mathrm{H}_{2} \mathrm{~S} \text { :homocysteine ratio }\end{array}$ & [95] \\
\hline Human & Healthy controls & $\begin{array}{l}\text { Gas chromatogra- } \\
\text { phy-mass spec- } \\
\text { trometry with } \\
\text { pentafluorobenzyl } \\
\text { bromide dramatiza- } \\
\text { tion }\end{array}$ & $\begin{array}{l}\text { Whole } \\
\text { frozen } \\
\text { blood }\end{array}$ & $35-80 \mu \mathrm{M}$ & Method evaluation paper. & [35] \\
\hline Human & Healthy volunteers & $\begin{array}{l}\text { Microdistillation } \\
\text { and ion chro- } \\
\text { matography }\end{array}$ & Plasma & $\begin{array}{l}\text { Levels differed with } \\
\text { varying dietary } \\
\text { meat intake Meat } \\
\text { free, } 42 \pm 15 \mu \mathrm{M} \\
240 \mathrm{~g} \text { meat, } 47 \pm \\
12 \mu \mathrm{M} 420 \mathrm{~g} \text { meat, } \\
25 \pm 0.8 \mu \mathrm{M}\end{array}$ & $\begin{array}{l}\text { This study also directly compared the } \\
\text { methylene blue assay with this chro- } \\
\text { matographic technique and found the } \\
\text { levels obtained in both systems to be } \\
\text { comparable }\end{array}$ & {$[36]$} \\
\hline Human & $\begin{array}{l}\text { Healthy volunteers } \\
\text { and septic shock } \\
\text { patients }\end{array}$ & $\begin{array}{l}\text { Zinc acetate / } \\
\text { DMPD }\end{array}$ & Plasma & $\begin{array}{l}\text { Age and sex } \\
\text { matched healthy } \\
\text { controls, } 43.8 \pm \\
5.1 \mu \mathrm{M} \text { Septic } \\
\text { shock, } 150.5 \pm \\
43.7 \mu \mathrm{M}\end{array}$ & & {$[14]$} \\
\hline
\end{tabular}

*Estimated by the authors from published figures.

$\mathrm{H}_{2} \mathrm{~S}$-derived species such as $\mathrm{HS}^{-}$and $\mathrm{S}^{2-}$ that exist at physiological $\mathrm{pH}$ rather than $\mathrm{H}_{2} \mathrm{~S}$ itself.

However, the majority of the reported studies been useful in generating a substantial amount of data for researchers to 'benchmark' their results and clearly highlight the emerging importance of $\mathrm{H}_{2} \mathrm{~S}$ and closely related species in the cardiovascular system. Levels of $\mathrm{H}_{2} \mathrm{~S}$ in the plasma measured using this spectrophotometric assay are generally comparable to other approaches (see Table 1). For example, Chen et al. [33] utilized a sulfide-selective electrode and detected serum $\mathrm{H}_{2} \mathrm{~S}$ levels in man of $37.9 \pm 0.9 \mu \mathrm{M}$ (healthy controls) cf. $33.0 \pm 0.7 \mu \mathrm{M}$ (smokers) and $51.1 \pm 3.0$ $\mu \mathrm{M}$ (chronic obstructive pulmonary disease [COPD] patients). Using a similar electrochemical method Chang et al. [34] reported plasma $\mathrm{H}_{2} \mathrm{~S}$ levels in rat of $30-50 \mu \mathrm{M}$. Furthermore, the analysis of human plasma by more laborious analytical techniques such as gas chromatography-mass spectrometry with pentafluorobenzyl bromide dramatization or microdistillation with ion chromatrgraphy revealed $\mathrm{H}_{2} \mathrm{~S}$ levels of $35-80 \mu \mathrm{M}$ [35] and 25-50 $\mu \mathrm{M}$ [36], respectively. We recently reported comparable serum levels of $\mathrm{H}_{2} \mathrm{~S}$ in healthy human volunteers using the methylene blue spectrophotometric assay and found mean serum levels ( \pm S.D.) of $43.8 \pm 5 \mu \mathrm{M}$ which were increased markedly (up to $200 \mu \mathrm{M}$ in one case) during septic shock [14]. As such, the methylene blue based spectrophotometric assay appears to be convenient, relatively robust and at least comparable to other techniques for the measurement of plasma $\mathrm{H}_{2} \mathrm{~S}$ ('free' $\mathrm{H}_{2} \mathrm{~S}, \mathrm{HS}^{-}$or $\mathrm{S}_{2}{ }^{-}$).

However, it is prudent to note that while the majority of laboratories report plasma $\mathrm{H}_{2} \mathrm{~S}$ in the region of $25-80 \mu \mathrm{M}$ it is important to note here that a few laboratories have reported markedly different findings using the same analytical techniques. For example, Chenyu et al. [37] have reported levels of in excess of $300 \mu \mathrm{M}$ in plasma from healthy rats whereas others $[38,39]$ have suggested that the actual level of $\mathrm{H}_{2} \mathrm{~S}$ in plasma was beyond the limit of detection for the methylene blue assay and electrochemical detectors (Table 1). Indeed, using rat tissue homogenates and head space gas chromatography Furne et al. [39] failed to detect tissue 
release of $\mathrm{H}_{2} \mathrm{~S}$ from the tissues into the head space after supplementing tissues with L-cysteine. These important studies do not necessarily contradict the majority of the reported findings in the literature (see Table 1) as they would suggest that $\mathrm{H}_{2} \mathrm{~S}$ is sequestered or carried in plasma and tissues rather than released as 'free' $\mathrm{H}_{2} \mathrm{~S}$. Indeed, it is intriguing to note here that when solutions of $\mathrm{H}_{2} \mathrm{~S}$ or the commonly used sulfide salt donors ( $\mathrm{Na}_{2} \mathrm{~S}$ and $\mathrm{NaHS}$ ) are prepared in the laboratory at concentrations reported in plasma, the solutions are characteristically pungent. However, blood, plasma, serum or tissue homogenates, while containing $\mathrm{H}_{2} \mathrm{~S}$ (Table 1) do not smell, further suggesting that the widely used assays could measure a form of bound or sequestered $\mathrm{H}_{2} \mathrm{~S}$ rather than 'free' $\mathrm{H}_{2} \mathrm{~S}$.

Whatever the absolute level of $\mathrm{H}_{2} \mathrm{~S}$ in plasma, it is likely that any reported plasma levels could represent an underestimate of the true extent of $\mathrm{H}_{2} \mathrm{~S}$ synthesis as pathways for $\mathrm{H}_{2} \mathrm{~S}$ removal exist (summarized in Fig. 1) although it is uncertain how rapid this process occurs in the vasculature. The half-life of $\mathrm{H}_{2} \mathrm{~S}$ in mammalian plasma has been estimated at $<30 \mathrm{~min}$. although the mechanism for this has not been identified [38]. A direct reaction with methemoglobin forming sulfhemoglobin has been suggested and it is possible that sulfhemoglobin could act as a 'sink' for circulating $\mathrm{H}_{2} \mathrm{~S}$ as it releases $\mathrm{H}_{2} \mathrm{~S}$ upon reduction. Intracellular pathways for $\mathrm{H}_{2} \mathrm{~S}$ removal also exist. In cells, $\mathrm{H}_{2} \mathrm{~S}$ is rapidly oxidized to thiosulfate $\left(\mathrm{S}_{2} \mathrm{O}_{3}{ }^{2-}\right)$ by mitochondria and subsequently converted to sulfite $\left(\mathrm{SO}_{3}{ }^{2-}\right)$ and the major and stable product, sulfate $\left(\mathrm{SO}_{4}{ }^{2-}\right)[40,41]$. Unfortunately, $\mathrm{SO}_{4}{ }^{2-}$ cannot be used as a 'bio-marker' of endogenous $\mathrm{H}_{2} \mathrm{~S}$ production since it can be derived from the direct oxidation of cysteine by cysteine dioxygenase (E.C. 1.13.11.20) and oxidation of $\mathrm{SO}_{3}{ }^{2-}$ by sulfite oxidase (E.C. 1.8.3.1) [42].

Urinary and blood $\mathrm{S}_{2} \mathrm{O}_{3}{ }^{2-}$ has been used as a marker of environmental $\mathrm{H}_{2} \mathrm{~S}$ inhalation $[43,44]$ and elevated urinary $\mathrm{S}_{2} \mathrm{O}_{3}{ }^{2-}$ has been measured in Down syndrome patients [45] with the suggestion that these reflected an overproduction of $\mathrm{H}_{2} \mathrm{~S}$ in Down syndrome patients although blood $\mathrm{S}_{2} \mathrm{O}_{3}{ }^{2-}$ levels were not determined in this study. However, $\mathrm{S}_{2} \mathrm{O}_{3}{ }^{2-}$ may not be completely reliable as an index of $\mathrm{H}_{2} \mathrm{~S}$ since $\mathrm{S}_{2} \mathrm{O}_{3}{ }^{2-}$ levels in blood without detection in urine have also been observed after industrial $\mathrm{H}_{2} \mathrm{~S}$ poisoning $[46,47]$ and urinary $\mathrm{S}_{2} \mathrm{O}_{3}{ }^{-}$in otherwise healthy individuals vary greatly and are sensitive to small fluctuations in atmospheric $\mathrm{H}_{2} \mathrm{~S}$ [47]. In animal studies where $\mathrm{SO}_{3}{ }^{2-}, \mathrm{SO}_{4}{ }^{2-}$ and $\mathrm{S}_{2} \mathrm{O}_{3}{ }^{2-}$ have been measured simultaneously, $\mathrm{H}_{2} \mathrm{~S}$ exposure resulted in a greater elevation of $\mathrm{SO}_{3}{ }^{2-}$ and $\mathrm{SO}_{4}{ }^{2-}$ compared to $\mathrm{S}_{2} \mathrm{O}_{3}{ }^{2-}$ in lung tissue [48]. Similarly, incubation of plasma, liver, colonic or muscle tissue with $\mathrm{H}_{2} \mathrm{~S}$ or one of its metabolites methanethiol (see below) also leads to $\mathrm{S}_{2} \mathrm{O}_{3}{ }^{2-}$ and $\mathrm{SO}_{4}{ }^{2-}$ generation [49]. These findings strongly suggest that the metabolism of $\mathrm{H}_{2} \mathrm{~S}$ in vivo is complex and the reliability of $\mathrm{S}_{2} \mathrm{O}_{3}{ }^{2-}$ as an index of endogenous $\mathrm{H}_{2} \mathrm{~S}$ synthesis requires further attention.

Further cellular $\mathrm{H}_{2} \mathrm{~S}$ removal processes also exist. For example, in the cytosol, $\mathrm{H}_{2} \mathrm{~S}$ also undergoes methylation in by thiol$S$-methyltransferase (E.C. 2.1.1.9) to yield methanethiol $\left(\mathrm{CH}_{3} \mathrm{~S}\right)$ and dimethylsulfide $\left(\mathrm{CH}_{3} \mathrm{SCH}_{3}\right)[49,50]$. An additional enzymatic removal process which is potentially important in colonic tissue involves rhodanese (thiosulfate : cyanide sulfurtransferase; E.C. 2.8.1.1) [51], an enzyme which catalyses the transfer of the sulfane sulfur atom from $\mathrm{HS}^{-}$to a thiophilic acceptor (such as cyanide) via an enzymic persulfide intermediate to form thiocyanate $\left(\mathrm{SCN}^{-}\right)$and $\mathrm{SO}_{4}{ }^{2-}$. $\mathrm{H}_{2} \mathrm{~S}$ can also be oxidized by activated neutrophils to $\mathrm{SO}_{3}{ }^{2-}$ [52] suggesting $\mathrm{H}_{2} \mathrm{~S}$ may represent an important source of $\mathrm{SO}_{3}{ }^{2-}$ in vivo. Furthermore, $\mathrm{H}_{2} \mathrm{~S}$ could also be consumed by endogenous oxidant species in the vasculature such as peroxynitrite [10], hypochlorite [23], superoxide [24, 25], hydrogen peroxide [24, 25] and nitric oxide [26], mediators also known to be produced in elevated amounts in various cardiovascular pathologies.

\section{$\mathrm{H}_{2} \mathrm{~S}$ in the heart and vasculature}

$\mathrm{H}_{2} \mathrm{~S}$ is emerging as a novel and an important physiological mediator in the cardiovascular system. Much of our current knowledge of the cardiovascular biology of $\mathrm{H}_{2} \mathrm{~S}$ stems from the use of inhibitors of CSE such as D,L-propargylglycine (PAG), $\beta$-cyanoalanine and inhibitors of CBS such as aminooxyacetic acid. These compounds apparently target the pyridoxal phosphate binding site of these enzymes [53] and may not be entirely specific. It should also be noted that although intraperitoneal injection of PAG results in its rapid accumulation into the blood (peak within $2 \mathrm{hrs}$ ), an as yet unidentified metabolite of PAG produced through the D-amino acid oxidase pathway injures the renal proximal tubule cells resulting in significant polyuria, proteinuria and glucosuria 5-6 hrs after injection [54]. As such, a possible diuretic and/or other renal effects of this PAG metabolite (or PAG itself) in mediating the effects of PAG (and $\mathrm{H}_{2} \mathrm{~S}$ ) on systemic blood pressure should be considered.

Nevertheless, in the present absence of wholly specific inhibitors in this emerging field of research, studies using PAG when combined with analytical techniques such as PCR, immunohistochemistry and Western blotting or more recently using animal knock-out models [55] have clearly shown CSE to be the more important of the two known $\mathrm{H}_{2} \mathrm{~S}$ synthesizing enzymes in the cardiovascular system $[55,56]$, where its expression is induced by pro-inflammatory mediators such as lipopolysaccharide and carrageenan but down-regulated during hypoxia, hypertension and myocardial infarction (see Table 1). In sharp contrast, very little is known about the role of $\mathrm{H}_{2} \mathrm{~S}$, CSE or CBS in human beings. To date only, one study has shown CSE to be present in human vascular tissue (internal mammary artery) [57] although it is known to be expressed in human liver [58] and leucocytes [59]. Nevertheless, the few emerging studies examining $\mathrm{H}_{2} \mathrm{~S}$ levels in human blood have clearly shown perturbed $\mathrm{H}_{2} \mathrm{~S}$ synthesis in coronary heart disease [60] and myocardial infarction, where lower $\mathrm{H}_{2} \mathrm{~S}$ levels have been suggested to reflect disease severity (see Table 1).

Although experiments in man and animals have clearly shown that removal of endogenous nitric oxide through inhibition of NOS (i.e. with L-NAME) rapidly increases blood pressure, contrasting effects of CSE inhibition (i.e. with PAG) have been reported. For example, injection of PAG exerted little immediate effect on blood 
pressure in normotensive anaesthetized rats [61, 62] but increased blood pressure after endotoxic [14] or haemorrhagic shock [52] when administered either prophylactically or therapeutically. This suggested CSE-derived $\mathrm{H}_{2} \mathrm{~S}$ as a pathological mediator in blood pressure homeostasis. In sharp contrast, longer-term injection of PAG in rats for 2-3 weeks significantly increased systolic blood pressure [63] suggesting the role of CSE was regulatory, rather than pathological. These disparities could either reflect the manner in which PAG was administered or merely the extent to which PAG is cell permeable in different animal models systems and different animal strains. Although PAG reduces $\mathrm{H}_{2} \mathrm{~S}$ levels in the plasma of various animal models (see Table 1) and the activity of CSE in isolated cells in vitro, it has been so far assumed that PAG is freely cell permeable. However, to the best of our knowledge, studies explicitly showing cellular uptake of PAG are lacking. Nevertheless, by far the most compelling evidence for the role of $\mathrm{H}_{2} \mathrm{~S}$ in the vasculature is from very recent studies using CSE single and double knock-out mice [55] where $\mathrm{CSE}^{-1-}$ and lesser extent $\mathrm{CSE}^{+/-}$mice had significantly higher systolic arterial blood pressure then $\mathrm{CSE}^{+/+}$mice. Furthermore, $\mathrm{CSE}^{-1-}$ mice were substantially more sensitive to $\mathrm{H}_{2} \mathrm{~S}$-mediated vasodilatation than wild-type mice [55].

Plasma or serum levels of $\mathrm{H}_{2} \mathrm{~S}$ in rat, mouse and human adult plasma vary between $\sim 23$ and $60 \mu \mathrm{M}$ (summarized in Table 1). Within these reported plasma concentration ranges, $\mathrm{H}_{2} \mathrm{~S}$ induces the relaxation and transient blood pressure reduction in a variety of vascular tissue such as rat aorta and portal vein $[64,65]$, rabbit corpus cavernosum [66] as well as perfused rat mesenteric [67] and hepatic [68] vascular beds. $\mathrm{H}_{2} \mathrm{~S}$ has been shown to be produced in myocardial tissue by CSE in vitro and in vivo to protect against hypoxia-reperfusion injury, where it exerts a negative inotropic effect and preserves left ventricular function by lowering left ventricular systolic and end diastolic pressure and reducing infarct size [25, 69-72]. The mechanism for the vasculoprotective effects $\mathrm{H}_{2} \mathrm{~S}$ (summarized in Table 2) may be mediated by a direct stimulation of plasma membrane $K_{\text {ATP }}$ channel-dependent vasorelaxation resulting in increased vascular flow. Rodent aortic ring preparations exposed to high concentrations of $\mathrm{K}^{+}$ions show markedly reduced vasorelaxant response to $\mathrm{H}_{2} \mathrm{~S}$ and $\mathrm{K}_{\text {ATP }}$ channel antagonists such as glibenclamide or 5-hydroxydecanoate (5HD) effectively blocked $\mathrm{H}_{2} \mathrm{~S}$-mediated vasodilatation [65, 70, 71]. Patch clamp studies using isolated rat mesenteric [73] and aortic [74] vascular smooth muscle cells exposed to $\mathrm{H}_{2} \mathrm{~S}$ show increased glibenclamide-inhibitable $\mathrm{K}_{\text {ATP-dependent }}$ current and cellular hyperpolarization [75]. However, $\mathrm{H}_{2} \mathrm{~S}$-mediated opening of $K_{\text {ATP }}$ channels does not occur in isolated rat cardiomyocytes [76] suggesting the effects of $\mathrm{H}_{2} \mathrm{~S}$ on $\mathrm{K}_{\text {ATP }}$ may be cell specific.

Additional pathways for $\mathrm{H}_{2} \mathrm{~S}$-mediated vasodilation have also been proposed. For example, $\mathrm{H}_{2} \mathrm{~S}$ activates adenylate cylcase and elevates CAMP in cultured neurons $[30,32]$ and isolated human vascular smooth muscle (HVSM) cells [77], suggesting a vasodilatory effect mediated through cAMP is also possible. On the other hand, the activation of this CAMP pathway was not observed in isolated rat cardiomyocytes where the inhibition of L-type $\mathrm{Ca}^{2+}$ channels was proposed [76] or rat vascular endothelial cells [78]. These findings further suggest cell and perhaps species specific effects of $\mathrm{H}_{2} \mathrm{~S}$ on vascular cells as have been observed with nitric oxide.

$\mathrm{H}_{2} \mathrm{~S}$ is further reported to stimulate charybdotoxin/apamin-sensitive $\mathrm{K}^{+}$channels in vascular endothelium $[73,75]$ although other laboratories have not observed this [79]. Nevertheless, it is highly likely that, as with nitric oxide the vascular endothelium represents the major target for $\mathrm{H}_{2} \mathrm{~S}[55,73,75,79]$. Consistent with this, reduced CSE expression/activity and decreased $\mathrm{H}_{2} \mathrm{~S}$ concentration contributes to the pathophysiology of pulmonary hypertension in rodents [80] whereas CBS deficiency leads to hyperhomocyst(e)inemia, increased blood pressure and endothelial dysfunction $[81,82]$. Although CBS is not considered to be the vascular source of $\mathrm{H}_{2} \mathrm{~S}$ [55], tissue deficiencies in CBS are thought to manifest in the vasculature as a consequence of homocysteine accumulation (reviewed in $[83,84]$ ). Homocysteine is directly toxic to vascular endothelial cells (reviewed in $[85,86]$ ) and induces apoptotic cell death [87], up-regulates surface expression of intracellular adhesion molecule (ICAM)-1 [88], augments monocyte adhesion [89] and promotes interleukin (IL)-1 $\beta$ and tumour necrosis factor- $\alpha$ formation [90] and interferes with vascular nitric oxide synthesis and bioavailability [91-94]. Interestingly, homocysteine treatment of Sprague-Dawley rats markedly increased plasma $\mathrm{H}_{2} \mathrm{~S}$ levels via increased expression and activity of CSE [34] and it is tempting to speculate that this response by vascular cells to synthesize vasodilatory $\mathrm{H}_{2} \mathrm{~S}$ in the presence of a detrimental vascular toxin was a protective and/or compensatory response to maintain vascular patency.

In rodents, CBS or CSE deficiency induced by genetic deletion or chronic treatment with PAG results in a severe hypertension and severe loss of endothelial function [55, 82]. Interestingly, a close examination of the published literature clearly shows that spontaneously hypertensive rats have lowered $\mathrm{H}_{2} \mathrm{~S}$ concentrations than rats from other species (i.e. WKY, Wistar, Sprague-Dawley) (Table 1). Furthermore, rodent models of pulmonary and hypoxic hypertension also show decreased plasma $\mathrm{H}_{2} \mathrm{~S}$ levels. In each case, the administration of the $\mathrm{H}_{2} \mathrm{~S}$ donor, NaHS, reduced blood pressure. Interestingly, children are reported to have higher plasma levels of $\mathrm{H}_{2} \mathrm{~S}$ than adults [95] and one study has shown that plasma $\mathrm{H}_{2} \mathrm{~S}$ concentrations are decreased with age in adults over 50-80 years old [33]. Together with the observation that $\mathrm{H}_{2} \mathrm{~S}$-mediated vasodilation is at least partly endothelium dependent $[65,73-75,79]$; this suggests that there is a possible loss of $\mathrm{H}_{2} \mathrm{~S}$ synthesizing capacity or bio-availability over time that parallels age-associated increases in blood pressure in man.

It is possible that part of the vasculoprotective effects may be due to inhibition of platelet aggregation [96]. However, this is unlikely since significant inhibition platelet aggregation by $\mathrm{H}_{2} \mathrm{~S}$ $(\sim 30 \mu \mathrm{M})$ at physiologically relevant concentrations was only observed with ADP and millimolar concentrations of NaHS were required to inhibit platelet aggregation induced by other mediators such as collagen, arachidonate and thrombin. It is further likely that $\mathrm{H}_{2} \mathrm{~S}$ removes toxic oxidants that are known to be detrimental to endothelial function in the vasculature [11, 23-26]. An additional protective effect, consistent with a potential antioxidant role of $\mathrm{H}_{2} \mathrm{~S}$, may be in limiting vascular protein modification such as 
Table 2 Summary of effects consistent with a protective role for $\mathrm{H}_{2} \mathrm{~S}$ in the vasculature

\begin{tabular}{|c|c|c|c|}
\hline Observation & Example & Comment & References \\
\hline \multirow[t]{5}{*}{ Antioxidant activity } & $\begin{array}{l}\text { Scavenging or removal of toxic radical and radi- } \\
\text { cal-derived intermediates (i.e. } \mathrm{ONOO}^{-}, \mathrm{HOCl}, \mathrm{O}_{2}^{-} \text {, } \\
\mathrm{H}_{2} \mathrm{O}_{2} \text {, nitric oxide) }\end{array}$ & $\begin{array}{l}\text { Cytoprotective effects observed in neuronal } \\
\text { cells but potent in vitro oxidant scavenging also } \\
\text { observed so it is possible the interaction with } \\
\mathrm{H}_{2} \mathrm{~S} \text { and these oxidants also occur in the vascu- } \\
\text { lature. Indeed, } \mathrm{H}_{2} \mathrm{O}_{2} / \mathrm{O}_{2}^{-} \text {'scavenging' pre- } \\
\text { vented myocardial injury in vitro. }\end{array}$ & {$[11,23-26]$} \\
\hline & & $\begin{array}{l}\text { 3-nitrotyrosine (a bio-marker for } \mathrm{ONOO}^{-} \text {) and } \\
\text { MDA levels (a bio-marker for lipid peroxida- } \\
\text { tion) in rat heart were reduced in a model of } \\
\text { myocardial ischemia reperfusion }\end{array}$ & [99] \\
\hline & $\begin{array}{l}\text { Inhibition of oxidative modification to low-density } \\
\text { lipoprotein }\end{array}$ & $\begin{array}{l}\text { Oxidation of low-density lipoprotein consid- } \\
\text { ered pro-atherogenic }\end{array}$ & [97] \\
\hline & $\begin{array}{l}\text { Inhibition of NADPH oxidase synthesis and } \mathrm{O}_{2}^{-} \\
\text {formation in human vascular smooth muscle cells }\end{array}$ & $\begin{array}{l}\text { Down-regulation of NADPH oxidase expres- } \\
\text { sion. Possible involvement of CAMP and pro- } \\
\text { tein kinase A }\end{array}$ & [77] \\
\hline & $\begin{array}{l}\text { NaHS induces glutathione (GSH) synthesis and } \\
\text { decreases plasma levels of oxidized glutathione } \\
\text { (GSSG). }\end{array}$ & $\begin{array}{l}\text { Effects observed in neuronal cells. Increased } \\
\text { cysteine uptake and increased activity of } \\
\gamma \text {-glutamylcysteine synthetase; GSH is an } \\
\text { effective extracellular and intracellular antioxi- } \\
\text { dant NaHS increased plasma total antioxidant } \\
\text { capacity }\end{array}$ & {$[21,22,30,114]$} \\
\hline \multirow[t]{7}{*}{ Effects on vascular cells } & $\begin{array}{l}\text { Inhibition of vascular smooth muscle cell prolifer- } \\
\text { ation }\end{array}$ & $\begin{array}{l}\text { Activation ERK and } \mathrm{p} 21^{\mathrm{cip} / \mathrm{WAF}} \text {-mediated path- } \\
\text { way; observed in rat and human cells either } \\
\text { treated with NaHS or through over-expression } \\
\text { of CSE. }\end{array}$ & {$[100,102]$} \\
\hline & & $\begin{array}{l}\text { However, inhibition of ERK has also been } \\
\text { reported. }\end{array}$ & [101] \\
\hline & Induction vascular smooth muscle cell apoptosis & $\begin{array}{l}\text { Human artery smooth muscle cells. ERK and } \\
\text { p38 MAPK activation, up-regulation of } \\
\text { p21 } 1^{\text {cip/wak-1 }} \text { and down-regulation of cyclin D1 } \\
\text { expression. Caspase-mediated cell death. }\end{array}$ & {$[103,104]$} \\
\hline & $\begin{array}{l}\text { Induction of endothelial cell adhesion, migration } \\
\text { and proliferation }\end{array}$ & AKT and PI-3K-dependent pathways & [98-102] \\
\hline & Inhibition of myocardial apoptosis & $\begin{array}{l}\text { Rat model of myocardial ischemia-reperfusion } \\
\text { injury. NaHS-mediated inhibition of apoptosis } \\
\text { was abolished by the putative mitochondrial } \\
\text { KATP channel inhibitor 2-HD. JNK, p38 and } \\
\text { NF-кB-dependent pathways also activated. }\end{array}$ & [99] \\
\hline & Promotion of angiogenesis & AKT pathway proposed. & [78] [99] \\
\hline & & $\begin{array}{l}\text { NaHS inhibited adhesion molecule expression } \\
\text { (ICAM-1) in rat model of myocardial ischemia } \\
\text { reperfusion }\end{array}$ & \\
\hline
\end{tabular}


Table 2 Continued

\begin{tabular}{|c|c|c|c|}
\hline Observation & Example & Comment & References \\
\hline \multicolumn{4}{|l|}{$\begin{array}{l}\mathrm{H}_{2} \mathrm{~S} \text { required for cardio- } \\
\text { vascular health }\end{array}$} \\
\hline \multirow[t]{6}{*}{ Vasodilator effects } & $\begin{array}{l}\text { Vasodilation via opening KATP channel in smooth } \\
\text { muscle and vascular endothelium; Induces relax- } \\
\text { ation and transient blood pressure reduction in } \\
\text { rat aorta, portal vein and mesenteric and hepatic } \\
\text { vascular beds; induces relaxation of rabbit corpus } \\
\text { cavernosum; induces relaxation in human internal } \\
\text { mammary artery. }\end{array}$ & $\begin{array}{l}\mathrm{H}_{2} \mathrm{~S} \text {-mediated vasodilation was endothelium } \\
\text { dependent and inhibitable by glibenclamide or } \\
5 \mathrm{HD} \text { suggesting KATP-channel-dependent } \\
\text { effects }\end{array}$ & $\begin{array}{l}{[57,64-68} \\
74-76,79]\end{array}$ \\
\hline & $\begin{array}{l}\text { Inhibition of angiotensin-converting enzyme activ- } \\
\text { ity of endothelial cells }\end{array}$ & $\begin{array}{l}\text { If this reaction occurred in vivo it could poten- } \\
\text { tially lead to vasodilation in vivo since inhibi- } \\
\text { tion of angiotensin-converting enzyme would } \\
\text { decrease plasma levels of the angiontensin-II } \\
\text { and decrease the breakdown of bradykinin. }\end{array}$ & [105] \\
\hline & & $\begin{array}{l}\text { Presumably the effect of } \mathrm{H}_{2} \mathrm{~S} \text { on angiotensin- } \\
\text { converting enzyme was due to } \mathrm{H}_{2} \mathrm{~S} \text {-interaction } \\
\text { with the active site } \mathrm{Zn}^{2+} \text { ions since exogenous } \\
\mathrm{Zn}^{2+} \text { prevented enzyme inhibition. However, } \\
\text { the effect could also be due to direct 'scaveng- } \\
\text { ing' effect of } \mathrm{Zn}^{2+} \text { ions on } \mathrm{H}_{2} \mathrm{~S} \text { as it is the } \\
\text { basis of the methylene blue assay }\end{array}$ & \\
\hline & $\begin{array}{l}\text { Activation of adenyl cyclase and cAMP-mediated } \\
\text { vasodilation }\end{array}$ & $\begin{array}{l}\text { NaHS increased cAMP in human vascular } \\
\text { smooth muscle cells; }\end{array}$ & [77] \\
\hline & & $\begin{array}{l}\text { NaHS also induces cAMP formation in cul- } \\
\text { tured neurons and macrophages suggesting } \\
\text { one additional mechanism for } \mathrm{H}_{2} \mathrm{~S} \text {-mediated } \\
\text { vasodilation is mediated through adenyl } \\
\text { cyclase / cAMP. }\end{array}$ & {$[30,32]$} \\
\hline & & $\begin{array}{l}\text { However this effect was not observed in iso- } \\
\text { lated rat cardiomyocytes or rat vascular } \\
\text { endothelial cells highlighting potential cell- } \\
\text { specific and species-dependent effects of } \mathrm{H}_{2} \mathrm{~S} \text {. }\end{array}$ & {$[75,77]$} \\
\hline \multirow[t]{4}{*}{$\begin{array}{l}\text { Low plasma levels impli- } \\
\text { cated in cardiovascular } \\
\text { disease }\end{array}$} & $\begin{array}{l}\text { Spontaneously hypertensive rats have lower } \\
\text { plasma } \mathrm{H}_{2} \mathrm{~S} \text { levels than normotensive WKY, } \\
\text { Wistar or Sprague-Dawley rats }\end{array}$ & $\begin{array}{l}\text { Data consistent with } \mathrm{H}_{2} \mathrm{~S} \text { as a physiological } \\
\text { regulator of blood pressure }\end{array}$ & $\begin{array}{l}\text { See Table } 1 \text { for } \\
\text { comparison of } \\
\text { levels between } \\
\text { different rat } \\
\text { strains }\end{array}$ \\
\hline & $\begin{array}{l}\text { Low CSE expression, activity and } \mathrm{H}_{2} \mathrm{~S} \text { levels con- } \\
\text { tribute to the pathology of hypertension, coronary } \\
\text { heart disease, angina, hypoxia and ischemia- } \\
\text { reperfusion injury }\end{array}$ & $\begin{array}{l}\text { Data consistent with } \mathrm{H}_{2} \mathrm{~S} \text { as a physiological } \\
\text { regulator of blood pressure and cardiac func- } \\
\text { tion; low plasma } \mathrm{H}_{2} \mathrm{~S} \text { reflected severity of car- } \\
\text { diovascular disease. }\end{array}$ & $\begin{array}{l}{[15,25,33,60} \\
61,79,95,110 \\
113,114][55]\end{array}$ \\
\hline & & $\begin{array}{l}\text { Low levels could suggest decreased } \mathrm{H}_{2} \mathrm{~S} \text { syn- } \\
\text { thesis or consumption by toxic intermediates } \\
\text { such as nitric oxide, } \mathrm{ONOO}^{-}, \mathrm{O}_{2}^{-} \mathrm{HOCl} \text { or } \mathrm{H}_{2} \mathrm{O}_{2} \text {. }\end{array}$ & \\
\hline & $\begin{array}{l}\mathrm{CSE}^{-/-} \text {mice have higher blood pressure than } \\
\mathrm{CSE}^{+/-} \text {and } \mathrm{CSE}^{+/+} \text {mice }\end{array}$ & & \\
\hline
\end{tabular}

Continued 
Table 2 Continued

\begin{tabular}{|c|c|c|c|}
\hline Observation & Example & Comment & References \\
\hline & $\begin{array}{l}\text { Slow release } \mathrm{H}_{2} \mathrm{~S} \text { donor decrease systolic blood } \\
\text { pressure in spontaneously hypertensive rats but } \\
\text { not normotensive WKY rats }\end{array}$ & $\begin{array}{l}\text { Effects of NaHS compared with a novel slow } \\
\text { releasing } \mathrm{H}_{2} \mathrm{~S} \text { donor; biphasic effects of } \mathrm{H}_{2} \mathrm{~S}\end{array}$ & [79] \\
\hline & Plasma $\mathrm{H}_{2} \mathrm{~S}$ levels decline with increasing age. & $\begin{array}{l}\mathrm{H}_{2} \mathrm{~S} \text {-mediated vasodilation is endothelium } \\
\text { dependent. Age-dependent increase in blood } \\
\text { pressure and endothelial dysfunction are well } \\
\text { documented. Data consistent with } \mathrm{H}_{2} \mathrm{~S} \text { as a } \\
\text { physiological regulator of blood pressure. }\end{array}$ & [33] \\
\hline & & $\begin{array}{l}\text { Interestingly, hypertensive children had lower } \\
\mathrm{H}_{2} \mathrm{~S} \text { than normotensive children. } \\
\text { Normotensive children have higher plasma } \\
\mathrm{H}_{2} \mathrm{~S} \text { than adults. }\end{array}$ & [95] \\
\hline \multicolumn{4}{|l|}{$\begin{array}{l}\text { Cardiovascular protective } \\
\text { effects of } \mathrm{H}_{2} \mathrm{~S}\end{array}$} \\
\hline \multirow[t]{5}{*}{$\begin{array}{l}\text { Protection against } \\
\text { myocardial ischemia- } \\
\text { reperfusion and myocar- } \\
\text { dial infarction injury }\end{array}$} & $\begin{array}{l}\text { Preserves left ventricular contractility and reduces } \\
\text { infarct size }\end{array}$ & $\begin{array}{l}\text { Opening of mitochondrial } \mathrm{K}_{\text {ATP }} \text { channels and } \\
\text { up-regulation of } \mathrm{BCl}_{2} \text { protein to prevent mito- } \\
\text { chondrial permeability and release of pro- } \\
\text { death factors (i.e. cytochrome c) i.e. } \mathrm{H}_{2} \mathrm{~S} \text { is } \\
\text { cytoprotective. Inhibition of c-Fos signalling. } \\
\text { Inhibition of pro-inflammatory signalling (p38, } \\
\text { JNK and NF-кB) }\end{array}$ & {$[69-72,99,115]$} \\
\hline & $\begin{array}{l}\text { Preservation of mitochondrial ultrastructure and } \\
\text { respiratory function during ischemia reperfusion }\end{array}$ & & \\
\hline & $\mathrm{H}_{2} \mathrm{~S}$ is a mediator in ischemic preconditioning & $\begin{array}{l}\mathrm{H}_{2} \mathrm{~S} \text { activated AKT, PKC. } \alpha \text { and PKC } \xi \text {-dependent } \\
\text { signalling }\end{array}$ & [121] \\
\hline & Inhibition of platelet aggregation & $\begin{array}{l}\text { Concentrations of } \mathrm{H}_{2} \mathrm{~S} \text { within the physiological } \\
\text { range }(\sim 30 \mu \mathrm{M}) \text { prevented ADP-induced } \\
\text { platelet aggregation. However, mM concentra- } \\
\text { tions of } \mathrm{H}_{2} \mathrm{~S} \text { required to inhibit platelet aggre- } \\
\text { gation via other mediators. Plasma } \mathrm{H}_{2} \mathrm{~S} \\
\text { unlikely to reach mM concentrations. }\end{array}$ & [96] \\
\hline & $\begin{array}{l}\text { Inhibition of L-type } \mathrm{Ca}^{2+} \text { channels in isolated rat } \\
\text { cardiomyocytes }\end{array}$ & $\begin{array}{l}\text { NaHS inhibited electricity-stimulated intracellu- } \\
\text { lar } \mathrm{Ca}^{2+} \text { mobilization in a KATP-channel inde- } \\
\text { pendent manner. Potential to reduced myocar- } \\
\text { dial hypertrophy and inhibit cardiomyocyte } \\
\text { apoptosis. }\end{array}$ & [76] \\
\hline
\end{tabular}

inhibiting $\mathrm{HOCl}-m e d i a t e d$ atherogenic modification of lowdensity lipoprotein and apolipoprotein and inhibit myeloperoxidase activity, presumably by interaction at the heme moiety of myeloperoxidase [97].

Alternatively, the cytoprotecitve effects of $\mathrm{H}_{2} \mathrm{~S}$ may be due to the initiation of 'protective cellular' signalling pathways within cardiac and vascular tissues. For example, $\mathrm{H}_{2} \mathrm{~S}$ induces extracellular regulated kinase (ERK) and protein kinase $B$ (AKT) signalling path- ways in cardiac tissue $[78,98,99]$ and preserves mitochondrial ultrastructure and respiratory chain function in vivo [72] possibly via a mitochondrial pathway involving the preservation of $\mathrm{Bcl}-2$ signalling and intriguingly, a mitochondrial $\mathrm{K}_{\text {ATP-Channel-dependent }}$ mechanism [99]. $\mathrm{H}_{2} \mathrm{~S}$ is also reported to induce vascular angiogenesis and induced neovascularization in mice in vivo as well as promote proliferation, adhesion and migration in cultured endothelial cells via AKT and phosphatidylinositol 3-kinase phosphorylation 
$[78,98]$. Furthermore, $\mathrm{H}_{2} \mathrm{~S}$ was recently shown to inhibit neointima formation after balloon injury in rat carotid artery in vivo by inhibiting vascular smooth muscle cell proliferation [100, 101], an effect also observed with HVSM cell proliferation in vitro by either inducing or inhibiting [101] ERK and p21 $1^{\mathrm{cip} / W A F}$ phosphorylation [102]. Furthermore a pro-apoptotic effect of $\mathrm{H}_{2} \mathrm{~S}$ on HVSM cells has also been proposed, also mediated through ERK/p21 $1^{\text {cip/wak-1 }}$ [103] and p38 pathways involving caspase-3 activation [103, 104] suggesting that the role of $\mathrm{H}_{2} \mathrm{~S}$ in the vasculature is to activate the endothelium and inhibit vascular smooth muscle cell function. Indeed, as with nitric oxide mediated vasorelaxation, the vasodilatatory effects of $\mathrm{H}_{2} \mathrm{~S}$ are endothelium dependent $[65,73-75,79]$.

An additional effect of $\mathrm{H}_{2} \mathrm{~S}$ may be due to the inhibition of angiotensin-converting enzyme on the surface of vascular endothelial cells [105] possibly resulting from an interaction of $\mathrm{H}_{2} \mathrm{~S}$ with the $\mathrm{Zn}^{2+}$ moiety at the enzyme's active site. Should the corresponding reaction occur in vivo this would result in vasodilation due to lowered circulating levels of the vasoconstrictor angiotensin-II and consequently decrease the breakdown of the vasodilator bradykinin. Since it is also likely that $\mathrm{H}_{2} \mathrm{~S}$ interacts with NOS3 and endothelial of release of nitric oxide, this suggests that these gases may be reciprocally regulated (see below). Indeed, $\mathrm{H}_{2} \mathrm{~S}$ appears to activate adenylate cyclase/cAMP $[30,32,77]$ signalling in certain cell types (but not others $[76,78]$ ) whereas nitric oxide mediated effects are via guanylate cyclase/cGMP perhaps suggestive of complementary or competing pathways for the control of vascular tone.

Although the bulk of these publications to date have suggested that $\mathrm{H}_{2} \mathrm{~S}$ is an endogenous vasodilator, concentrations of $\mathrm{H}_{2} \mathrm{~S}$ towards the lower end of that measured physiologically have also shown that $\mathrm{H}_{2} \mathrm{~S}$ induces endothelium-dependent vasoconstriction in rat [65] and human arteries [57]. In nonmammalian vertebrates, $\mathrm{H}_{2} \mathrm{~S}$ induces vasorelaxation or vasoconstriction (or both) $[13,106]$. In isolated bovine pulmonary arteries $\mathrm{H}_{2} \mathrm{~S}$ causes tissue contraction whereas it induces a complex contraction-relaxation-contraction response in rat pulmonary arteries [106]. Indeed closer examination of the pioneering publications which examined the vasodilator effects of $\mathrm{H}_{2} \mathrm{~S}$ on isolated rat aortic rings clearly show that low concentrations of $\mathrm{H}_{2} \mathrm{~S}$ induce contraction $[74,75,80]$. Although this was not stated in the text of these publications, these findings are clearly visible in the published figures. We recently expanded these early studies and showed that in phenylephrine precontracted rat aortic ring preparations [65] and isolated human internal mammary artery [57], low concentrations of $\mathrm{H}_{2} \mathrm{~S}$ induced tissue contraction followed by relaxation. Both of these effects were dependent on intact endothelial cells since denuded tissue showed neither tissue contraction (at low $\mathrm{H}_{2} \mathrm{~S}$ concentrations) or relaxation (at higher $\mathrm{H}_{2} \mathrm{~S}$ concentrations) [65]. Furthermore we also showed that low concentrations of $\mathrm{H}_{2} \mathrm{~S}$-induced endothelium-dependent vasoconstriction in vitro and in anaesthetized rats this was inhibited by removal of endogenous nitric oxide with L-NAME [65] again suggesting molecular 'cross-talk' between $\mathrm{H}_{2} \mathrm{~S}$ and nitric oxide.

\section{Evidence for 'cross-talk' between nitric oxide and $\mathrm{H}_{2} \mathrm{~S}$}

$\mathrm{H}_{2} \mathrm{~S}$-induced vasorelaxation is only partially blocked by glibenclamide when used at a concentration of $10 \mu \mathrm{M}[57,65,73-75,79]$, which is an appropriate concentration for KatP specificity. This implies the involvement of additional $K_{\text {ATP-dependent mechanisms }}$ for these vascular effects. Together with the studies highlighted above, these findings strongly suggest the possibility of 'cross-talk' between vascular nitric oxide and $\mathrm{H}_{2} \mathrm{~S}$. However, the precise nature of such an interaction has proved difficult to characterize accurately. Recent studies in vascular tissue and cells from several species have shown $\mathrm{H}_{2} \mathrm{~S}$ either acts at the level of NOS, nitric oxide influences CSE activity and that $\mathrm{H}_{2} \mathrm{~S}$ (or species derived from it at physiological $\mathrm{pH}$ ) interact with vascular-derived nitric oxide and vice versa with apparent formation of a 'nitrosothiol'-like species. A summary of the present evidence consistent with cross-talk between $\mathrm{H}_{2} \mathrm{~S}$ and nitric oxide is presented in Table 3 .

The direct effects of $\mathrm{H}_{2} \mathrm{~S}$ on NOS activity has been investigated with mixed results and as appears common for the emerging area of $\mathrm{H}_{2} \mathrm{~S}$ biology, the mechanisms for these observations have not been fully investigated. For example Kubo et al. [107, 108] showed recombinant NOS1 (rat), NOS2 (mouse) and to a latter extent, NOS3 (bovine) were inhibited by NaHS perhaps through interfering with tetrahydrobiopterin binding. Work by others $[63,109-111]$ subsequently showed that $\mathrm{H}_{2} \mathrm{~S}$ inhibited NOS3 but not NOS2 activity in isolated rat and mouse aortic rings [107] and in human umbilical vein endothelial (HUVE) cells [109]. However, the lack of effect of NOS2 is not surprising since NOS2 is an inducible protein and was not induced in these experiments. Nevertheless, further experiments showed that intraperitoneal injection of NaHS into rats significantly reduced plasma $\mathrm{NO}_{2}{ }^{-} / \mathrm{NO}_{3}{ }^{-}$levels and suggested inhibition of NOS3 activity [109]. However, in each of these studies, free nitric oxide, $\mathrm{H}_{2} \mathrm{~S}$ or $S$-nitrosothiols were not measured. It is therefore possible that the lowered $\mathrm{NO}_{2}{ }^{-} / \mathrm{NO}_{3}{ }^{-}$levels in plasma, as an index of nitric oxide, reflected the consumption of nitric oxide by either the added $\mathrm{H}_{2} \mathrm{~S}$ gas, the added $\mathrm{H}_{2} \mathrm{~S}$ donor (NaHS) or endogenously produced $\mathrm{H}_{2} \mathrm{~S}$ via L-cysteine/pyridoxal phosphate in these studies.

It is also possible that $\mathrm{H}_{2} \mathrm{~S}$ exerts its effects on nitric oxide synthesis via modulation of NOS substrate availability. For example in a rat model of pulmonary hypertension, induced by abdominal aorta-inferior cava vein shunt, L-arginine up-regulated CSE expression and $\mathrm{H}_{2} \mathrm{~S}$ synthesis in pulmonary artery smooth muscle cells [111, 112]. However, in rat aortic tissue and HUVE cells $\mathrm{H}_{2} \mathrm{~S}$ gas or $\mathrm{H}_{2} \mathrm{~S}$ generated via L-cysteine/pyridoxal decreased Larginine uptake and $\mathrm{NO}_{2}{ }^{-} / \mathrm{NO}_{3}{ }^{-}$formation through an apparently $\mathrm{K}_{\text {ATP }}$ sensitive pathway [109], suggesting $\mathrm{H}_{2} \mathrm{~S}$ could serve as a negative regulator of nitric oxide synthesis.

The effects of nitric oxide donors on $\mathrm{H}_{2} \mathrm{~S}$ synthesis have also been investigated with species and tissue-dependent effects and contradictory findings reported. For example, the nitric oxide donor, sodium nitroprusside (SNP) up-regulates $\mathrm{H}_{2} \mathrm{~S}$ production in rat vascular tissues and brain by increasing the expression of 
Table 3 Evidence consistent with nitric oxide- $\mathrm{H}_{2} \mathrm{~S}$ cross-talk in the cardiovascular system

\section{Cardiovascular observation \\ Involvement in common cardiovascular pathology}

Endogenous $\mathrm{H}_{2} \mathrm{~S}$ and nitric oxide levels negatively correlate with blood pressure and cardiac function

Haemorrhagic and endotoxic shock induce elevated $\mathrm{H}_{2} \mathrm{~S}$ and nitric oxide synthesis; prophylactic and therapeutic pharmacological inhibition of CSE or NOS2 is protective

Inflammation and oedema are associated with elevated $\mathrm{H}_{2} \mathrm{~S}$ and nitric oxide levels; inhibition of CSE or NOS decreases inflammation and swelling

\section{Stimulatory effects of $\mathrm{H}_{2} \mathrm{~S}$ on nitric oxide synthesis and nitric oxide mediated vasorelaxation}

The nitric oxide donor sodium nitroprusside (SNP) enhanced CBS activity and $\mathrm{H}_{2} \mathrm{~S}$ levels in vitro and increased $\mathrm{H}_{2} \mathrm{~S}$ synthesis in rat aortic, liver and ileum $[63,112]$

The vasorelaxant effect of the nitric oxide donors SNP and SIN-1 were enhanced by incubating rat aortic tissue with NaHS [64]

L-NAME inhibited $\mathrm{H}_{2} \mathrm{~S}$-mediated vasorelaxation in rat aorta and the conversion of L-cysteine to $\mathrm{H}_{2} \mathrm{~S}$ in rat aortic tissue. This effect was enhanced by treatment with the nitric oxide donor SNP [73]

NaHS $[64,65]$ or slow release $\mathrm{H}_{2} \mathrm{~S}$ donor GYY4137 [79] prevented and reversed L-NAME-mediated hypertension in rats

$\mathrm{H}_{2} \mathrm{~S}$ potentiated expression of NOS2 following stimulation of cultured rat vascular muscle cells with interleukin (IL)- $1 \beta$

$\mathrm{H}_{2} \mathrm{~S}$ inhibited nitric oxide generation in isolated aortic tissues and in vivo [109] H2S down-regulated NOS3 (eNOS) but not NOS2 (iNOS) expression however, NOS2 was not induced [107, 108]

$\mathrm{H}_{2} \mathrm{~S}$, NaHS inhibited L-arginine uptake in human umbilical vein endothelial (HUVE) cells [109, 110]

L-cysteine / pyridoxdal phosphate inhibited L-arginine uptake in HUVE cells; inhibited by PAG [109, 110]

L-Arginine increased CSE mRNA expression in pulmonary vascular endothelial and smooth muscle cells [110]

Nitric oxide donors up-regulated the expression and activity of CSE in vascular tissues and cultured aortic smooth muscle cells [74, 124]

Synergistic effect of nitric oxide and $\mathrm{H}_{2} \mathrm{~S}$ on stonustoxin-induced relaxation of isolated rat aorta [123]

Synergistic effect of nitric oxide and $\mathrm{H}_{2} \mathrm{~S}$ on rat pulmonary artery relaxation [64]

$\mathrm{H}_{2} \mathrm{~S}$-mediated ischemic after conditioning involved activation of NOS3 [121]

\section{Inhibitory effects of $\mathrm{H}_{2} \mathrm{~S}$ on nitric oxide synthesis and nitric oxide mediated vasorelaxation}

NaHS inhibited recombinant NOS1 (nNOS) and NOS3 (eNOS) activity through interaction with $\mathrm{BH}_{4}$ and NOS2 through unknown mechanisms [107-109]

L-NAME inhibited CSE expression and $\mathrm{H}_{2} \mathrm{~S}$ synthesis in thoracic artery and superior mesenteric artery in rats [80]

Nitric oxide dependent relaxation of rat aortic rings through either nitric oxide donors (SNP, SNAP or SIN-1) or nitric oxide dependent (acetylcholine, histamine) but not nitric oxide independent (i.e. isoprenaline) mediators was inhibited by exogenous $\left(\mathrm{H}_{2} \mathrm{~S}\right.$ gas, NaHS) and endogenous (L-cysteine/pyridoxal phosphate) $\mathrm{H}_{2} \mathrm{~S}$; an effect reversed by PAG [65]

L-NAME inhibited $\mathrm{H}_{2} \mathrm{~S}$-induced increase in mean arterial blood pressure in anaesthetized rats [65]

$\mathrm{H}_{2} \mathrm{~S}$ inhibited vasorelaxation of isolated human internal mammary artery; induced by nitric oxide dependent mechanisms (i.e. acetylcholine) [57] PAG inhibited SNP-mediated vasorelaxation of isolated rat aorta [114]

\section{Other evidence of RNS- $\mathrm{H}_{2} \mathrm{~S}$ interaction}

Scavenging' of $\mathrm{ONOO}^{-}$; inhibition of $\mathrm{ONOO}^{-}$-mediated cell death, intracellular protein nitration and tyrosine nitration in vitro [11] Inhibition of tyrosine nitration in vivo in animal model of myocardial ischemia reperfusion [99]

Several nitric oxide donors react with NaHS in vitro to form a species resembling an inert 'nitrosothiol' [11, 26, 57, 65]

$\mathrm{H}_{2} \mathrm{~S}$-dependent nitrosothiol formation during lipopolysaccharide-induced septic shock in the rat [26]

NaHS-mediated decrease of $\mathrm{O}_{2}{ }^{-}$formation in human vascular smooth muscle cells was inhibited by the nitric oxide donor spermine NONOate [77] 
CSE or CBS [110-112] suggesting a possible interaction of these gases at the expression of their synthesizing enzymes. In rat aortic tissue, the vasorelaxant effect of SNP was enhanced in the presence of NaHS. At the level of vascular smooth muscle cells, $\mathrm{H}_{2} \mathrm{~S}$ has been reported to either enhance [63] or to attenuate $[65,75]$ the relaxant effect of nitric oxide in the rat aorta and human internal mammary artery [57]. Furthermore, NaHS-mediated inhibition of $\mathrm{O}_{2}{ }^{-}$production in HVSM was attenuated by nitric oxide (supplied as spermine NONOate) [64]. However, it is also possible that $\mathrm{O}_{2}{ }^{-}$was consumed by nitric oxide (forming $\mathrm{ONOO}^{-}$) or 'scavenged' by $\mathrm{H}_{2} \mathrm{~S}$ [23-26].

\section{Evidence for the formation of a novel intermediate between nitric oxide and $\mathrm{H}_{2} \mathrm{~S}$ at physiological $\mathrm{pH}$}

Given the reportedly high concentrations of $\mathrm{H}_{2} \mathrm{~S}$ in the vasculature (Table 1) and the extensive tyrosine nitration (as a bio-marker for $\mathrm{ONOO}^{-}$) and $\mathrm{NO}_{2}{ }^{-} / \mathrm{NO}_{3}{ }^{-}$(as bio-markers for nitric oxide) observed in human tissues and fluids, (especially during pathology [4-7]), the reaction between $\mathrm{H}_{2} \mathrm{~S}$ and $\mathrm{ONOO}^{-}$is plausible. Indeed, $\mathrm{H}_{2} \mathrm{~S}$ was recently shown to react with $\mathrm{ONOO}^{-}$(or species derived from it at physiological $\mathrm{pH}$ ) to inhibit nitrosative stress, cellular 3-nitrotyrosine formation and accompanying cell death [11]. However, since the half life of $\mathrm{ONOO}^{-}$at $\mathrm{pH} 7.4$ and $37^{\circ} \mathrm{C}$ is $<1 \mathrm{sec}$. [4-6], a much more plausible reaction is between nitric oxide (or intermediates derived from it) with $\mathrm{H}_{2} \mathrm{~S}$, especially since plasma levels of $\mathrm{NO}_{2}{ }^{-}$(indicative of nitric oxide synthesis) are reported to reach high concentrations during chronic inflammation, oedema and sepsis; the precise conditions in which $\mathrm{H}_{2} \mathrm{~S}$ synthesis is stimulated. Indeed, spectrophotometric, amperometric and electron paramagnetic resonance spectroscopy have recently shown that $\mathrm{H}_{2} \mathrm{~S}$ (or intermediates derived from it at physiological $\mathrm{pH}$ ) also reacts with nitric oxide (or derived species at physiological $\mathrm{pH}$ ) to form a novel nitrosothiol-like compound(s) [26]. Further, incubation of RAW264.7 cells with nitric oxide donors (but not NaHS) resulted in cGMP accumulation but in sharp contrast, pre-mixing the nitric oxide donor SNP with NaHS did not result in cGMP formation unless $\mathrm{Cu}^{2+}$ was added to release nitric oxide. This finding suggests that the 'nitrosothiol' did not increase cGMP levels itself but only after release of nitric oxide [26] and that this 'nitrosothiol' molecule was a relatively inert under these conditions. It is therefore tempting to speculate that the "nitrosothiol'-like molecule may act as a sink for regulating nitric oxide and/or $\mathrm{H}_{2} \mathrm{~S}$ bioavailability.

The $\mathrm{H}_{2} \mathrm{~S}$-nitric oxide interaction has also been investigated ex vivo and in vivo using exogenous and endogenously produced $\mathrm{H}_{2} \mathrm{~S}$ and nitric oxide. In rat aortic ring preparations the addition several nitric oxide donors (SNP, SIN-1, SNAP) to phenylephirine pre-contracted rat aortic rings resulted in substantial relaxation but the subsequent addition of $\mathrm{NaHS}$ or authentic $\mathrm{H}_{2} \mathrm{~S}$ gas resulted in marked inhibition or reversal of nitric oxide donormediated relaxation [65]. However, pre-mixing nitric oxide donors with NaHS did not result in aortic ring relaxation unless $\mathrm{Cu}^{2+}$ was added to release nitric oxide from $\mathrm{H}_{2} \mathrm{~S}$-nitric oxide [52] again suggesting that the 'nitrosothiol'-like molecule formed through the interaction of nitric oxide with $\mathrm{H}_{2} \mathrm{~S}$ at physiological $\mathrm{pH}$ was inert. In addition, in isolated rat aortic rings [65] and human internal mammary artery [57], nitric oxide dependent (i.e. using histamine or acetylcholine) but not nitric oxide independent relaxation (i.e. using isoprenaline) was substantially inhibited by low concentrations of $\mathrm{NaHS}$ or $\mathrm{H}_{2} \mathrm{~S}$ gas and this effect removed or reversed by the addition of $\mathrm{Cu}^{2+}$ [65]. Nitric oxide dependent relaxation was also inhibited by the addition of L-cysteine/pyridoxal phosphate (as CSE substrate/co-factor), an effect reversed by the CSE inhibitor PAG [65]. Furthermore, we also showed that in liver homogenates from LPS-treated rats, 'nitrosothiol' formation was enhanced after the addition of Lcysteine/pyridoxidal phosphate but inhibited by inclusion of PAG in the incubate [26]. These results suggest that $\mathrm{H}_{2} \mathrm{~S}$ and nitric oxide or species derived from them at physiological $\mathrm{pH}$, reacted together to form a molecule (presumably a nitrosothiol) which exhibited little or no vasorelaxant activity either in vitro or in vivo. Unfortunately, at present the precise identity, molecular structure and physiological properties of this nitrosothiol-like species are currently unknown.

\section{Concluding remarks}

The precise role of $\mathrm{H}_{2} \mathrm{~S}$ under physiological and/or pathophysiological conditions remains unclear. The molecular interaction between NOS-CSE, nitric oxide-CSE, $\mathrm{H}_{2} \mathrm{~S}-\mathrm{NOS}$ and nitric oxide- $\mathrm{H}_{2} \mathrm{~S}$ are illdefined and require further attention. However, from the studies outlined above, it is likely that the physiological role of $\mathrm{H}_{2} \mathrm{~S}$ might be to suppress the vasodilator effect of nitric oxide through two distinct mechanisms; inhibition of NOS3 and 'scavenging' of nitric oxide resulting in the enhancement of vascular contractility. Conversely, under pathophysiological conditions whereby nitric oxide and $\mathrm{H}_{2} \mathrm{~S}$ synthesis are greatly increased (i.e. sepsis and shock) the vasculoprotective action of $\mathrm{H}_{2} \mathrm{~S}$ and $\mathrm{H}_{2} \mathrm{~S}$-mediated nitric oxide 'quenching' are lost resulting in excessive and pathological loss of vascular tone. The isolation and molecular identification of the nitrosothiol-like species derived from $\mathrm{H}_{2} \mathrm{~S}$ and nitric oxide will greatly facilitate the unravelling of the complex interaction between these gases and could address the varied and contradictory reports on the physiology and pathophysiology of $\mathrm{H}_{2} \mathrm{~S}$ and nitric oxide.

\section{Acknowledgements}

We thank the Peninsula Medical School (M.W.), the Northcott Devon Medical Foundation (M.W.) and King's College, University of London (P.K.M.) for their generous research support. 


\section{References}

1. Integrated Risk Information System. (2003) Toxicological review of hydrogen sulphide. U.S. Environmental Protection Agency EPA/635/R-03/005 [www. document]. URL http://www.epa.gov/ncea/iris/toxreviews/ 0061-tr.pdf [accessed September 1, 2008]. CAS No. 7783-06-4.

2. Leigh GJ. Nomenclature of inorganic chemistry recommendations. IUPAC Chemical Data Series; 1990. pp. 1-3.

3. McNaught A. Spelling of sulfur. J. Mat. Chem. 1991; 5: 716-16.

4. Pacher P, Beckman JS, Liaudet L. (2007). Nitric oxide and peroxynitrite in health and disease. Physiol Rev. 2007; 87: 315-424.

5. Greenacre SAB, Ischiropoulos H. Tyrosine nitration: localisation, quantification, consequences for protein function and signal transduction. Free Radic Res. 2001; 34: 541-81.

6. Halliwell B, Zhao K, Whiteman M. Nitric oxide and peroxynitrite. The ugly, the uglier and the not so good: a personal view of recent controversies. Free Radic Res. 1999; 31: 651-9.

7. Wimalawansa SJ. Nitric oxide: new evidence for novel therapeutic indications. Expert Opin Pharmacother. 2008; 9: 1935-54.

8. Seddon MD, Chowienczyk PJ, Brett SE, Casadei B, Shah AM. Neuronal nitric oxide synthase regulates basal microvascular tone in humans in vivo. Circulation. 2008; 117: 1991-6.

9. Giles TD. Aspects of nitric oxide in health and disease: a focus on hypertension and cardiovascular disease. Clin Hypertens. 2006; 8: 2-16.

10. Bath PM, Willmot M, Leonardi-Bee J, Bath FJ. Nitric oxide donors (nitrates), Larginine, or nitric oxide synthase inhibitors for acute stroke. Cochrane Database Syst Rev. 2002; 4: DOI: 10.1002/14651858. CD000398.

11. Whiteman M, Armstrong JS, Chu SH, Siau J-L, Cheung NS, Halliwell B, Moore PK. The novel neuromodulator hydrogen sulphide: an endogenous peroxynitrite 'scavenger'? J Neurochem. 2004; 90: 765-8.

12. Mester A, Fraser PE, Tice SV. Enzymatic desulfuration of $\beta$-mercaptopyruvate to pyruvate. J Biol Chem. 1954; 206: 516-75.

13. Dombkowski RA, Russel MJ, Olson KR. Hydrogen sulfide as an endogenous regulator of vascular smooth muscle tone in trout. Am J Physiol Regul Integr Comp Physiol. 2004; 286: R678-85.
14. Li L, Bhatia M, Zhu Y-Z, Zhu YC, Ramnath RD, Wang ZJ, Anuar FBM, Whiteman M, Salto-Tellez M, Moore PK. Hydrogen sulfide is a novel mediator of lipopolysaccharide-induced inflammation in the mouse. FASEB J. 2005; 19: 1196-8.

15. Yusuf M. Huat BTKH, Hsu A, Whiteman M, Bhatia M, Moore PK. Streptozotocininduced diabetes in the rat is associated with enhanced tissue hydrogen sulfide biosynthesis. Biochem Biophys Res Commun. 2005; 333: 1146-52.

16. Bhatia M, Wong FL, Fu D, Lau HY, Moochhala SM, Moore PK. Role of hydrogen sulfide in acute pancreatitis and associated lung injury. FASEB J. 2005; 19: 623-5.

17. Mnke M, Kraus JP, Ohura T \& Franke U. The gene for cystathionine beta-synthase (CBS) maps to the subtelomeric region on human chromosome $21 \mathrm{q}$ and to proximal mouse chromosome 17. Am J Hum Gene. 1988; 42: 550-9.

18. Ge Y, Jensen TL, Matherly LH, Taub JW. Transcriptional regulation of the human cystathionine beta-synthase-1b basal promoter: synergistic transactivation by transcription factors NF-Y and Sp1/Sp3. Biochem J. 2001; 357: 97-105.

19. Maclean KN, Janosik M, Kraus E, Kozich V, Allen RH, Raab BK, Kraus JP. Cystathionine beta-synthase is coordinately regulated with proliferation through a redox-sensitive mechanism in cultured human cells and Saccharomyces cerevisiae. J Cell Physiol. 2002; 192: 81-92.

20. Prudova A, Bauman Z, Braun A, Vitvistky V, Lu SC, Banergee R. S-adenosylmethionine stabilizes cystathionine beta-synthase and modulates redox capacity. Proc Natl Acad Sci USA. 2006; 103: 6489-94.

21. Kimura $\mathbf{Y}$, Dargush $\mathbf{R}$, Schubert $\mathbf{D}$, Kimura H. Hydrogen sulfide protects HT22 neuronal cells from oxidative stress. Antioxid Redox Signal. 2006; 8: 661-70.

22. Kimura Y, Kimura H. Hydrogen sulphide protects neurons from oxidative stress. FASEB J. 2004; 18; 1165-7.

23. Whiteman M, Cheung NS, Zhu Y-Z, Chu SH, Siau J-L, Wong BS, Armstrong JS, Moore PK. Hydrogen sulphide; a novel inhibitor of hypochlorous acid mediated oxidative damage in the brain? Biochem Biophys Res Commun. 2005; 326: 794-8.

24. Chang L, Geng B, Yu F, Zhao J, Jiang H, Du J, Tang C. Hydrogen sulfide inhibits myocardial injury induced by homocys- teine in rats. Amino Acids. 2008; 34: 573-85.

25. Geng B, Chang L, Pan C, Qi, Y, Zhao J, Pang Y, Du J, Tang C. Endogenous hydrogen sulfide regulation of myocardial injury induced by isoproterenol. Biochem Biophys Res Commun. 2004; 318: 756-63.

26. Whiteman M, Li L, Kostetski I, Chu SH, Siau J-L, Bhatia M, Moore PK. Evidence for the formation of a novel nitrosothiol from the gaseous mediators nitric oxide and hydrogen sulfide. Biochem Biophys Res Commun. 2006; 343: 303-10.

27. Ishii I, Akahoshi N, Yu XN, Kobayahsi Y, Namekata K, Komaki G, Kimura H. Murine cystathionine gamma-lyase: complete CDNA and genomic sequences, promoter activity, tissue distribution and developmental expression. Biochem J. 2004; 381: 13-23.

28. Dominy JE, Stipanuk MH. New roles for cysteine and transsulfuration enzymes: production of $\mathrm{H}_{2} \mathrm{~S}$, a neuromodulator and smooth muscle relaxant. Nutr Rev. 2004; 62: 348-53.

29. Cheung NS, Peng ZF, Chen JM, Moore PK, Whiteman M. Hydrogen sulfide induced neuronal cell death occurs via glutamate receptor activation and is associated with calpain activation and lysosomal rupture in mouse primary cortical neurons. Neuropharmacol. 2007; 53: 505-14.

30. Kimura H. Hydrogen sulfide as a neuromodulator. Mol Neurobiol. 2002; 26: 13-9.

31. Lawrence NS, Davis J, Compton RG. Analytical strategies for the detection of sulfide: a review. Talanta. 2000; 52: 771-84.

32. Li L, Moore PK. Putative biological roles of hydrogen sulfide in health and disease: a breath of not so fresh air? Trends Pharmacol Sci. 2008; 29: 84-90.

33. Chen Y-H, Yao W-Z, Geng B, Ding Y-L, Lu M, Zhao M-W, Tang C-S. Endogenous hydrogen sulfide in patients with COPD. Chest. 2005; 128: 3205-11.

34. Chang L, Geng B, Yu F, Zhao J, Jian H, Du J, Tang C. Hydrogen sulfide inhibits myocardial injury induced by homocysteine in rats. Amino Acids. 2008; 34: 573-85.

35. Hyspler R, Ticha A, Indrova M, Zakak ZK, Hysplerova L, Gasparic, J, Churacek J. A simple, optimized method for the determination of sulphide in whole blood by GC-MS as a marker of bowel fermentation 
processes. J Chromatog B: Anal Tech Biomed Life Sci. 2002; 770: 255-9.

36. Richardson CJ, Magee EAM, Cummings $\mathrm{JH}$. A new method for the determination of sulphide in gastrointestinal contents and whole blood by microdistillation and ion chromatography. Clin Chem Acta. 2000; 293: 115-25.

37. Chunyu Z, Junabao, D, Dingfang B, Hui Y, Ziuying T, Chaoshu T. The regulatory effect of hydrogen sulfide on hypoxic pulmonary hypertension in rats. Biochem Biophys Res Commun. 2003; 302: 810-6.

38. Whitfield NL, Kreimier EL, Verdial FC, Skovgaard N, Olson KR. A Reappraisal of $\mathrm{H} 2 \mathrm{~S} /$ sulfide concentration in vertebrate blood and its potential significance in ischemic preconditioning and vascular signaling. Am J Physiol Regul Integr Comp Physiol. 2008; 294: R1930-7.

39. Furne J, Saeed A, Levitt MD. Whole Tissue Hydrogen Sulfide Concentrations are Orders of Magnitude Lower than Presently Accepted Values. Am J Physiol Regul Integr Comp Physiol. 2008; 295: R1479-85.

40. Goubern M, Andriamihaja M, Nubel T, Blachier F, Bouillaud F. Sulfide, the first inorganic substrate for human cells. FASEB J. 2007; 21: 1699-706.

41. Hildebrandt TM, Grieshaber MK. Three enzymatic activities catalyze the oxidation of sulfide to thiosulfate in mammalian and invertebrate mitochondria. FEBS J. 2008; 275: 3352-61.

42. Millard J, Parsons RB, Waring RH, Williams AC, Ramsden DB. Expression of cysteine dioxygenase (E.C. 1.13.11.20) and sulfite oxidase in the human lung: a potential role for sulfate production in the protection from airborne xenobiotica. Mol Pathol. 2003; 56: 270-4.

43. Kage S, Nagata T, Takekawa K, Kimura K, Kudo K, Imamura T. The usefulness of thiosulfate as an indicator of hydrogen sulfide poisoning in forensic toxicological examination: A study with animal experiments. Jpn. J. Forensic Toxicol. 1992; 10: 223-7.

44. Milby TH, Baselt RC. Hydrogen sulfide poisoning: Clarification of some controversial issues. Am J Ind Med. 1999; 35: 192-5.

45. Berlardinelli MC, Chabli A, ChadefauxVekemans B, Kamoun P. Urinary sulfur compounds in Down syndrome. Clin Chem. 2001; 47: 1500-1.

46. Kage S, Ikeda H, Ikeda N, Tsujita A, Kudo K. Fatal hydrogen sulfide poisoning at a dye works. Legal Med. 2004; 6: 182-6.
47. Durand $\mathbf{M}$, Weinstein P. Thiosulfate in human urine following minor exposure to hydrogen sulfide: implications for forensic analysis of poisoning. Forensic Toxicol. 2007; 25: 92-5.

48. Dorman DC, Moulin FJ, McManus BE, Mahle KC, James RA, Struve MF. Cytochrome oxidase inhibition induced by acute hydrogen sulfide inhalation: correlation with tissue sulfide concentrations in the rat brain, liver, lung, and nasal epithelium. Toxicol Sci. 2002; 65; 18-25.

49. Furne J, Springfield J, Koenig T, DeMaster E, Levitt MD. Oxidation of hydrogen sulfide and methanethiol to thiosulfate by rat tissues: a specialized function of the colonic mucosa. Biochem Pharmacol. 2001; 62: 255-9.

50. Levitt MD, Furne J, Springfield J, Suarez F, DeMaster E. Detoxification of hydrogen sulfide and methanethiol in the cecal mucosa. J Clin Invest. 1999; 104; 1107-14.

51. Ramasamy S, Singh S, Taniere $\mathbf{P}$, Langman MJ, Eggo MC. Sulfide-detoxifying enzymes in the human colon are decreased in cancer and upregulated in differentiation. Am J Physiol Gastrointest Liver Physiol. 2006; 291: G288-96.

52. Mitsuhashi H, Yamashita S, Ikeuchi H, Kuroiwa T, Kaneko Y, Hiromura K, Ueki K, Nojima Y. Oxidative stress-dependent conversion of hydrogen sulfide to sulfite by activated neutrophils. Shock. 2005; 24 : 529-34.

53. Johnston M, Jankowski D, Marcotte $\mathbf{P}$, Tanaka H, Esaki N, Soda K, Walsh C. Suicide inactivation of bacterial cystathionine gamma-synthase and methionine gamma-lyase during processing of Lpropargylglycine. Biochemistry. 1979; 18: 4690-701.

54. Konno R, Ikeda M, Yamaguchi K, Ueda Y, Niwa A. Nephrotoxicity of D-propargylglycine in mice. Arch Toxicol. 2000; 74; 473-9.

55. Yang G, Wu L, Jiang B, Yang W, Qi J, Cao K, Meng Q, Mustafa AK, Mu W, Zhang S, Snyder SH, Wang R. H2S as a physiologic vasorelaxant: hypertension in mice with deletion of cystathionine gamma-lyase. Science. 2008; 322: 587-90.

56. Chen C-Q, Xin H, Zhu Y-Z. Hydrogen sulfide: third gaseous transmitter, but with great pharmacological potential. Acta Pharmacol Sin. 2007; 28: 1709-16.

57. Webb GD, Lim LH, Oh VMS, Yeo SB, Cheong YP, Ali, MY, Oakley RE, Lee CN, Wong PS, Caleb MG, Salto-Tellez M, Bhatia M, Chan ESY, Taylor EA, Moore PK. Contractile and vasorelaxant effects of hydrogen sulfide and its biosynthesis in the human internal mammary aterty. $J$ Pharmacol Exp Therap. 2008; 324: 876-82.

58. Levonen AL, Lapatto R, Saksela M, Raivio KO. Human cystathionine- $\gamma$-lyase: developmental and in vitro expression of two isoforms. Biochem J. 2000; 347: 291-5.

59. Glode LM, Epstein M, Smith GA. Reduced cystathionine- $\gamma$-lyase protein content in human malignant leukemia cell lines as measured by immunoassay with monoclonal antibody. Cancer Res. 1981; 41: 2249-54.

60. Jiang HL, Wu HC, Li ZL, Geng B, Tang CS. Changes of the new gasesous transmitter $\mathrm{H}_{2} \mathrm{~S}$ in patients with coronary heart disease. Di Yi Jun Yi Da Xue Xue Bao. 2005; 25: 951-4.

61. Yan H, Du J, Tang C. The possible role of hydrogen sulfide on the pathogenesis of spontaneous hypertension in rats. Biochem Biophys Res Commun. 2004; 313: 22-7.

62. Mok Y-Y P, Atan MSBM, Ping CY, Ping WZ, Bhatia M, Moochala S, Moore KP. Role of hydrogen sulphide in hemorrhagic shock in the rat: protective effect of inhibitors of hydrogen sulphide biosynthesis. Br J Pharmacol. 2004; 143: 881-9.

63. Zhao W, Ndisang JF, Wang R. Modulation of endogenous production of $\mathrm{H} 2 \mathrm{~S}$ in rat tissues. Can J Physiol Pharmacol. 2003; 81: 848-53.

64. Hosoki R, Matsuki N, Kimura H. The possible role of hydrogen sulfide as an endogenous smooth muscle relaxant in synergy with nitric oxide. Biochem Biophys Res Commun. 1997; 237: 527-31.

65. Ali MY, Cheong YP, Mok Y-YP, Whiteman M, Bhatia M, Moore PK. Effect of hydrogen sulfide and nitric oxide alone and together on rat aortic contractility and blood pressure. Br J Pharmacol. 2006; 149: 625-34.

66. Srilatha B, Adaikan PG, Li L, Moore PK. Hydrogen sulphide: a novel endogenous gasotransmitter facilitates erectile function. J Sex Med. 2007; 4; 1304-11.

67. Cheng Y, Ndisan JF, Tang G, Cao K, Wang R. Hydrogen sulfide-induced relaxation of resistance mesenteric artery beds of rats. Am J Physiol Heart Circ Physiol. 2004; 287: H2316-23.

68. Fiorucci S, Antonelli E, Mencarelli A, Orlandi S, Renga B, Rizzo G, Distrutti E, Shah V, Morelli, A. The third gas: $\mathrm{H}_{2} \mathrm{~S}$ regulates perfusion pressure in both the isolated and perfused normal rat liver and in cirrhosis. Hepatol. 2005: 42; 539-48. 
69. Pan TT, Feng ZN, Lee SW, Moore PK, Bian JS. Endogenous hydrogen sulfide contributes to the cardioprotection by metabolic inhibition preconditioning in the rat ventricular myocytes. J Mol Cell Cardiol. 2006; 40: 119-30.

70. Zhu YZ, Wang Z.J, Ho P, Loke YY, Zhu YC, Huang XW, Huang SH, Tan CS, Whiteman M, Lu J, Moore PK. Hydrogen sulfide and its cardioprotective effects in myocardial ischemia in experimental rats. J Appl Physiol. 2007; 102; 261-8.

71. Johansen D, Ytrehus K, Baxter GF. Endogenous hydroden sulfide $\left(\mathrm{H}_{2} \mathrm{~S}\right)$ protects against regional myocardial ischemia-reperfusion injury. Evidence for a role of $K_{\text {ATP }}$ channels. Basic Res Cardiol. 2006; 101: 53-60.

72. Elrod JW, Calvert JW, Morrison J, Doeller JE, Kraus DW, Tao L, Jiao X, Kiss L, Szabo C, Kimura H, Chow CW, Lefer DJ. Hydrogen sulfide attenuates myocardial ischemia-reperfusion injury by preservation of mitochondrial function. Proc Natl Acad Sci USA. 2007; 104: 15560-5.

73. Zhao W Zhang J, Lu Y, Wang R. The vasorelaxant effect of $\mathrm{H}_{2} \mathrm{~S}$ as a novel endogenous gaseous KatP channel opener. EMBO J. 2001; 20: 6008-16.

74. Tang G, Wu L, Liang W, Wang R. Direct stimulation of K(ATP) channels by exogenous and endogenous hydrogen sulfide in vascular smooth muscle cells. Mol Pharmacol. 2005; 68: 1757-64.

75. Zhao W, Wang R. H2S induced vasorelaxation and underlying cellular and molecular mechanisms. Am J Physiol Heart Circ Physiol. 2002; 283: H474-80.

76. Sun YG, Cao YX, Wang WW, Ma SF, Yao T, Zhu YC. Hydrogen sulfide is an inhibitor of L-type calcium channels and mechanical contraction in rat cardiomyocytes. Cardiovasc Res. 2008; 79: 632-41.

77. Muzzaffar S, Shukla N, Bond M, Newby AC, Angelini GD, Sparatore A, Del Soldato P, Jeremy J. Exogenous hydrogen sulfide inhibits superoxide formation, NOX-1 expression and Rac 1 activity in human vascular smooth muscle cells. $J$ Vasc Res. 2008; 45: 521-8.

78. Cai WJ, Wang MJ, Moore PK, Jin HM, Yao T, Zhu YC. The novel proangiogenic effect of hydrogen sulfide is dependent on Akt phosphorylation. Cardiovasc Res. 2007; 76: 29-40.

79. Li L, Whiteman M, Tan CH, Guan YY, Neo $\mathrm{KL}$, Cheng $\mathrm{Y}$, Lee SH, Zhao Y, Baskar R, Moore PK. Characterisation of a novel, water soluble hydrogen sulfide releasing molecule (GYY4137): new insights into the biology of hydrogen sulphide. Circulation. 2008; 117: 2351-60.

80. Zhong G, Chen F, Cheng, Y, Tang C, Du J. The role of hydrogen sulfide generation in the pathogenesis of hypertension in rats induced by inhibition of nitric oxide synthase. J Hypertension. 2003; 21: 1879-85.

81. Clarke R, Daly L, Robinson K, Naughten E, Cahalane S, Fowler B. Hyperhomocysteinemia: an independent risk factor for vascular disease. N Engl J Med. 1991; 324: 1149-55.

82. Eberhardt RT, Forgione MA, Cap A, Leopold JA, Rudd MA, Trolliet M. Endothelial dysfunction in a murine model of mild hyperhomocyst(e)inemia. J Clin Invest. 2000; 106: 483-91.

83. Wierzbicki AS. Homocysteine and cardiovascular disease: a review of the evidence. Diab Vasc Dis Res. 2007; 4: 143-50.

84. Faeh D, Chiolero A, Paccaud $F$. Homocysteine as a risk factor for cardiovascular disease: should we (still) worry about? Swiss Med Wkly. 2006; 136: 745-56.

85. McKinely MC. Nutritional aspects and possible pathological mechanisms of hyperhomocysteinaemia: an independent risk factor for vascular disease. Proc Nutr Soc. 2000; 59: 221-37.

86. Moat SJ, Lang D, McDowell IF, Clarke ZL, Madhavan AK, Lewis MJ, Goodfellow J. Folate, homocysteine, endothelial function and cardiovascular disease. I Nutr Biochem. 2004; 15: 64-79.

87. Suhara T, Fukuo K, Yasuda $\mathbf{0}$, Tsubakimoto M, Takemura Y, Kawamoto H, Yokai T, Mogi M, Kaimoto T, Ogihara T. Homocysteine enhances endothelial apoptosis via upregulation of Fas-mediated pathways. Hypertension. 2004; 43: 1208-13.

88. Xu D, Neville R, Finkel T. Homocysteine accelerates endothelial cell senescence. FEBS Lett. 2000; 470: 20-4.

89. Koga T, Claycombe K, Meydani M. Homocysteine increases monocyte and Tcell adhesion to human aortic endothelial cells. Atherosclerosis. 2002; 161: 365-74.

90. Dalal S, Parkin SM, HomerVanniasinkam S, Nicolaou A. Effect of homocysteine on cytokine production by human endothelial cells and monocytes. Ann Clin Biochem. 2003; 40: 534-41.

91. Fu, WY, Dudman NP, Perry NP, Wang XL. Homocysteine attenuates hemodynamic responses to nitric oxide in vivo. Atherosclerosis. 2002; 161: 169-76.

92. Stamler JS, Osborne JA, Jaraki 0, Rabbani LE, Mullins M, Singel D, Loscalzo J. (1993) Adverse effects of homocysteine are modulated by endothelium-derived relaxing factor and oxides of nitrogen. J Clin Invest. 2003; 91: 308-18.

93. Upchurch GR, Welch GN, Fabian AJ, Freedman JE, Johnson JL, Keaney JF, Loscalzo J. Homocyst(e)ine decreases bioavailable nitric oxide by a mechanism involving glutathione peroxidase. $J$ Biol Chem. 1997; 272: 17012-7.

94. Upchurch GR, Welch GN, Loscalzo J. Homocysteine, EDRF and endothelial function. J Nutrition. 1996; 126: 1290S-4S.

95. Chen L, Sumou I, Ding Y-G, Liu Y, Qi J-G, Tang C-S, Du J-B. Imbalance of endogenous homocysteine and hydrogen sulfide metabolic pathway in essential hypertensive children. Chin Med J. 2007; 120: 389-93.

96. Zagli G, Patacchini R, Trevisani M, Abbate R, Cinotti S, Gensini G, Masotti G, Geppetti P. Hydrogen sulfide inhibits human platelet aggregation. Eur $J$ Pharmacol. 2007; 559: 65-8.

97. Laggner H, Meullner MK, Schreier S, Sturm B, Hermann M, Exner M, Gmeiner M, Gmeiner BM, Kapiotis S. Hydrogen sulphide: a novel physiological inhibitor of LDL atherogenic modification by $\mathrm{HOCl}$. Free Radic Res. 2007; 41: 741-7.

98. Hu Y, Chen X, Pan TT, Neo KL, Lee SW, Khin ES, Moore PK, Bian JS. Cardioprotection induced by hydrogen sulfide preconditioning involves activation of ERK and PI3K/Akt pathways. Pflugers Arch. 2008; 455: 607-16.

99. Sivarajah A, Collino M, Yasin M, Benetti E, Gallicchio M, Mazzon E, Cuzzocrea S, Fantozzi R, Thiemermann C. Antiapoptotic and anti-inflammatory effects of hydrogen sulfide in a rat model of regional myocardial I/R. Shock. 2009; 31: 267-74.

100. Meng QH, Yang G, Yang W, Jiang B, Wu L, Wang R. Protective effect of hydrogen sulfide on balloon injury-induced neointima hyperplasia in rat carotid arteries. Am J Pathol. 2007; 170: 1406-14.

101. Du J, Hui J, Cheung Y, Bin H, Jiang X, Chen C, Tang C. The possible role of hydrogen sulfide as a smooth muscle cell proliferation inhibitor in rat cultured cells. Heart Vessels. 2004; 19: 75-80.

102. Yang G, Cao K, Wu L, Wang R. Cystathionine gamma-lyase overexpression inhibits cell proliferation via a H2Sdependent modulation of ERK1/2 phosphorylation and p21Cip/WAK-1. J Biol Chem. 2004; 279: 49199-205.

103. Yang G, Wu L, Wang R. Pro-apoptotic effect of endogenous H2S on human aorta 
smooth muscle cells. FASEB J. 2006; 20: 553-5.

104. Yang G, Sun X, Wang R. Hydrogen sulfide-induced apoptosis of human aorta smooth muscle cells via the activation of mitogen-activated protein kinases and caspase-3. FASEB J. 2004; 18: 1782-4.

105. Laggner H, Hermann M, Esterbauer H, Muellner MK, Exner M, Gmeiner BM, Kapiotis S. The novel gaseous vasorelaxant hydrogen sulfide inhibits angiotensinconverting enzyme activity of endothelial cells. J Hypertens. 2007; 25: 2100-4.

106. Olson KR, Dombkowksi RA, Russell MJ, Doellman MM, Head SK, Whitfield NL, Madden JA. Hydrogen sulfide as an oxygen sensor/transducer in vertebrate hypoxic vasoconstriction and hypoxic vasodilation. J Exp Biol. 2006; 209: 4011-23.

107. Kubo S, Doe I, Kurokawa Y, Nishikawa H, Kawabata A. Direct inhibition of endothelial nitric oxide synthase by hydrogen sulfide: contribution to dual modulation of vascular tension Toxicol. 2007; 232: 138-46.

108. Kubo S, Kurokawa Y, Doe I, Masuko T, Sekiguchi F, Kawabata A. Hydrogen sulfide inhibits activity of three isoforms or recombinant nitric oxide synthase. Toxicol. 2007; 241: 92-7.

109. Geng B, Cui Y, Zhao J, Yu F, Zhu Y, Xu G, Zhang Z, Tang C, Du J. Hydrogen sulfide downregulates the aortic L-arginine/nitric oxide pathway in rats. Am J Physiol Regul Integr Comp Physiol. 2007; 293: R1608-18.

110. Yanfei W, Lin S, Du J, Tang C. Impact of L-arginine on hydrogen sulfide/cystathionine$\gamma$-lyase pathway in rats with high blood flow-induced pulmonary hypertension.
Biochem Biophys Res Commun. 2006; 345: 851-7.

111. Xiaohui L, Junbao D, Lin S, Jian L, Xiuying $\mathrm{T}$, Jianguang $\mathbf{Q}$, Bing $\mathbf{Q}$, Hongfang $\mathbf{H}$, Chaoshu $\mathrm{T}$. Down-regulation of endogenous hydrogen sulfide pathway in pulmonary hypertension and pulmonary vascular structural remodeling induced by high pulmonary blood flow in rats. Circ $J$. 2005; 69: 1418-24.

112. Eto K, Kimura H. A novel enhancing mechanism for hydrogen sulfide-producing activity of cystathionine $\beta$-synthase. $J$ Biol Chem. 2002; 277: 2680-5.

113. Li L, Rossoni G, Sparatore A, Lee LC, Del Soldato P, Moore PK. Anti-inflammatory and gastrointestinal effects of a novel diclofenac derivative. Free Radic Biol Med. 2007; 42: 706-19.

114. Wei HL, Zhang CY, Jin HF, Tang CS, Du JB. Hydrogen sulfide regulates lung tissue-oxidized glutathione and total antioxidant capacity in hypoxic pulmonary hypertensive rats. Acta Pharmacol Sin. 2008; 29: 670-9.

115. Zhu XY, Yan XH, Yan XH, Chen SJ. H2S protects myocardium against ischemia/ reperfusion injury and its effect on c-Fos protein expression in rats. Sheng $\mathrm{Li}$ Xue Bao. 2008; 60: 221-7.

116. Bhatia M, Sidhapuriwala JN, Ng SW, Tamizhselvi R, Moochhala SM. Pro-inflammatory effects of hydrogen sulphide on substance $\mathrm{P}$ in caerulein-induced acute pancreatitis. J Cell Mol Med. 2008; 12: 580-90.

117. Bhatia M, Wong FL, Fu D, Lau HY, Moochhala SM, Moore PK. Role of hydrogen sulfide in acute pancreatitis and associated lung injury. FASEB J. 2005; 19: 623-5.
118. Zhang H, Zhi L, Moore PK, Bhatia M. Role of hydrogen sulfide in cecal ligation and puncture-induced sepsis in the mouse. Am J Lung Cell Mol. Physiol. 2006; 290: L1193-201.

119. Branceleone V, Roviezzo F, Vellecco V, De Gruttola L, Bucci M, Cirino G. Biosynthesis of $\mathrm{H}_{2} \mathrm{~S}$ is impaired in nonobese diabetic (NOD) mice. Brit $J$ Pharmacol. 2008; 155: 673-80.

120. Chen Y-H, Yao W-Z, Ding Y-L, Geng B, Lu M, Tang C-S. Effect of theophylline on endogenous hydrogen slfide production in patients with COPD. Pulmon. Pharmacol Therapeut. 2008; 21: 40-6.

121. Yong QC, Lee SW, Foo CS, Neo KL, Chen X, Bian JS. Endogenous hydrogen sulphide mediates the cardioprotection induced by ischemic postconditioning. Am J Physiol Heart Circ Physiol. 2008; 295: H1330-40.

122. Jeong S-O, Pate H-O, Oh G-S, Jeong G-S, Lee B-S, Lee S, Kim DY, Rhew HY, Lee KM, Chung H-T. Hydrogen sulfide potentiates interleukin-1 $\beta$-induced nitric oxide production via enhancement of extracellular signal-regulated kinase activation in rat vascular smooth muscle cells. Bioche. Biophys Res Commun. 2006; 345: 938-44.

123. Liew HC, Khoo HE, Moore OK, Bhatia M, Lu J, Moochhalla SM. Synergism between hydrogen sulfide $(\mathrm{H}(2) \mathrm{S})$ and nitric oxide (NO) in vasorelaxation induced by stonustoxin (SNTX), a lethal and hypotensive protein factor isolated from stonefish Synanceja horrida venom. Life Sci. 2007; 80: 1664-8.

124. Wang YF, Mainali P, Tang CS, Shi L, Zhang CY, Yan H, Lui ZQ, Du JB. Effects of nitric oxide and hydrogen sulfide on the relaxation of pulmonary arteries in rats. Chin Med J. 2008; 121: 420-3. 